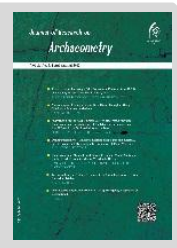

Original Paper

\title{
Evaluation of Environmental Factors in the Formation of Parthian Settlements in Sarakhs Plain
}

\author{
Davood Behroozifar', Reza MehrAfarin ${ }^{2 *}$, Mohammad Reza Saeedi³, Ahmad Chaychi \\ Amirkhiz ${ }^{4}$ \\ 1 PhD Candidate of Historical Archeology, Islamic Azad University, Science and Research Branch, Tehran, \\ IRAN \\ 2 Professor, Department of Archeology, University of Mazandaran, IRAN \\ ${ }^{3}$ Research Associate Research Institute for Humanities Research and Development Research and \\ Development Organization (Samt), Tehran, IRAN \\ ${ }^{3}$ Assistant Professor, Cultural Heritage and Tourism Research Institute, Iranian Center for Archaeological \\ Research, Tehran, IRAN
}

$\begin{array}{ll}\text { Received: 07/21/2020 } & \text { Accepted: 10/29/2020 }\end{array}$

\begin{abstract}
Due to the Parthian origin in northeastern Iran, Sarakhs plain (Fig. 1) was the subject of a methodical field study to gain an understanding of the process and how to establish and influence both nature and man in the region. The result of this study was the identification of fourteen settlement sites from this period, which can be considered and evaluated from the perspective of environmental factors and the size of the sites.

Keywords: Sarakhs plain, archaeology, Parthian settlement pattern, environmental factors.

\section{Introduction}

In the studies of the Parthian period of Khorasan, this period can be divided into two sub-periods: A: the period of formation of the Parthian empire and B: the period of the Parthian empire. The first period (formation of the Parthian empire) after the last phase of the Iron Age of the region called Yaz III (includes the end of the Achaemenid period) which covers from $300 \mathrm{BC}$ until the reign of First Mehrdad. The second stage of Parthian empire after the formation and recognition of the Parthian dynasty coincides with the reign of Mithridates I (also Mithradates I or Mihrdad I), which continued until the end of the decline of Parthian rule by Ardeshir Babakan [4].
\end{abstract}

\section{Materials and Methods}

The basis of dating is the typical pottery sherds and coins obtained from the surface of the sites, which in terms of typological traits are comparable with the pottery samples from Bandian Dargaz [8,9], Nesa [10], Merv in Turkmenistan [11] and other regions in western. The extent and continuity of settlements showed that this plain has a direct relationship with the facilities and environmental conditions; in such a way that the quantity and quality of settlements have increased with the increase of settlements compared to the previous period. Evidence of Parthian settlements in the present study was analyzed in the context of various natural factors such as distance from the river, land shape, altitude, communication roads, climate, vegetation and soil type.

One of the most important factors in the formation and distribution of the sites is height and roughness. Of the 14 Parthian sites of Sarakhs, three sites with a height of more than 900 to 1100

\footnotetext{
* Corresponding author: reza.mehrafarin@gmail.com

Copyright(C) 2020, the Authors / This open-access article is published under the terms of the Creative Commons Attribution-NonCommercial 4.0 International License which permits Share (copy and redistribute the material in any - medium or format) and Adapt (remix, transform, and build upon the material) under the Attribution NonCommercial terms.
} 
meters and three others at a relatively high altitude of almost foothills with a height of 600 to 800 meters and eight sites are located and formed in the plain at a height of less than 600 meters (Fig. 3). Another environmental component is water resources and rivers. It is expected that the Parthian sites of Sarakhs plain are often formed and scattered due to the water resources of the plain. Among the water resources of Sarakhs plain, the Parthian sites of this region were studied from the perspective of proximity to rivers. The most important rivers of Sarakhs plain are: 1- Harirood river 2- Shorlugh river 3- Tajan river [6.] Of the fourteen Parthian sites in the Sarakhs plain, eight sites are located less than 400 meters from the rivers. One site is situated between 2500 and 3000 meters of river $(4 \%)$ and the other five sites $(36 \%)$ are more than 3000 meters away from permanent rivers (Fig. 4). In the discussion of effective factors in the formation and dispersal of Parthian sites of Sarakhs plain, communication routes are another effective factor in their formation, expansion and dispersion. In terms of location, it is quite clear that this plain has always been of great importance along important ancient roads such as the Silk Road for cultural, commercial and economic relations between East and West. Ten of the fourteen Parthian settlements of Sarakhs plain are located between 400 and 1000 meters, two between 1000 and 2000 meters and the other two sites are located between 2000 and 2500 meters from the main communication roads. This factor shows the prominent role of communication roads in the formation and distribution of Parthian site of the Sarakhs plain (Fig. 5). Other factors include the shape of the land or the geomorphological structure of the natural environment of the region. Sarakhs plain consist of relatively flat lands with low wrinkle and short altitudes are formed and the elevations in this area do not have significant climatic stratification. Accordingly, the distribution of Sarakhs plain settlements are represented in the form of land shape (mountainous and plain) (Fig. 6). Another influential factor in the formation of settlements is climatic classes. In general, Sarakhs plain has a hot and dry climate in the plain, as well as temperate and mountainous in the highlands. The southern parts of the plain are temperate and mountainous, with cold and snowy winters but mild summers. Based on the obtained data, the highest climatic range in the plain is hot and dry climate, then temperate and humid in Bazangan region and then mountainous in the heights of Mozdooran (Table 2) and the highest distribution of residential settlements formed in the plain and then in two temperate and mountainous climates (Fig. 7). Another potential factor influencing the distribution of Parthian settlements in the Sarakhs plain is soil. The soil in each region has different capabilities for different agricultural products, thus affecting the livelihood structure of the region. In the analysis of the dispersion of the settlements in the study area, the location pattern of these settlements in terms of soil type has been considered. Accordingly, the effect of soil type on the formation of Sarakhs plain settlements has been shown (Fig. 8). Another effective component in the formation and distribution of ancient sites is the type of land use. Due to the location of most of the Sarakhs Parthian sites in the plains and due to the permanent rivers, the economy of most of these sites is probably based on agriculture.

\section{Results}

One of the most important results of the present study is identifying fourteen settlements with rich evidences from the Parthian period and analyzing their formation based on environmental factors and components, as well as reconstruction of part of the Parthian culture in northeastern Khorasan and establishing a relative chronology of the Sarakhs plain, in the framework of classification and typology as well as typology of pottery samples.

\section{Discussion}

Using the analytic hierarchy process technique, the environmental factors affecting the distribution of settlements have been analyzed and ranked. Calculate the average of settlements and divide the points by seven (number of environmental factors). These averages provide comparable criteria in which access to water resources and distance from streams, altitude and communication roads have the highest score, and the other components mentioned have the lowest score and amount (Fig. 10).

\section{Conclusion}

The output of maps and data of Parthian settlements in the region showed that among the environmental factors affecting the formation of settlements, the distance and proximity or location 
of settlements along rivers (linear settlement pattern), communication roads (Nessa and Silk Road), altitude and roughness in locating settlements in the altitude range between 300 to 1100 meters above sea level and how they are distributed in the Sarakhs plain and also altitudes in the formation of settlements has been more influential than other environmental factors. Other variables, namely climate, land use and soil type, have had a direct importance and impact on the distribution of Sarakhs plain settlements, respectively. 


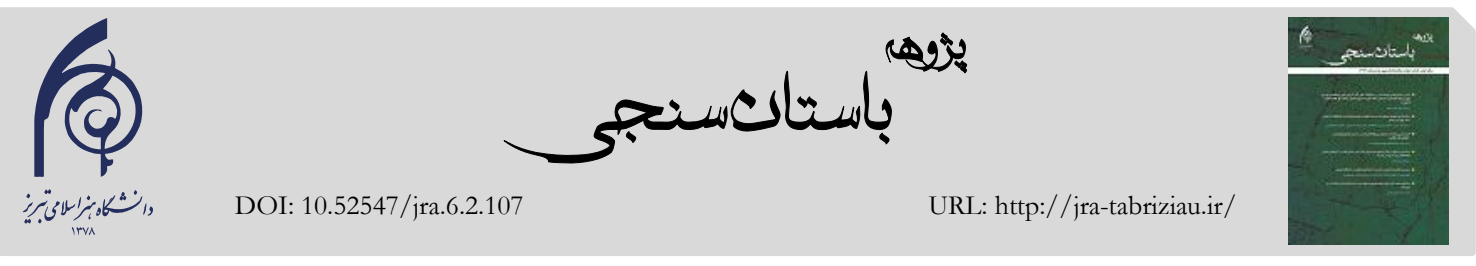

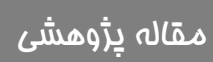

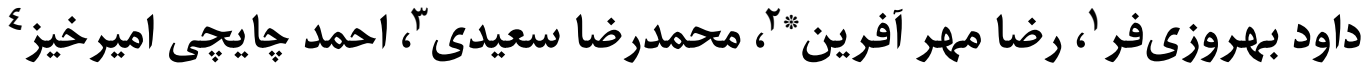

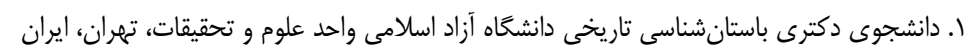

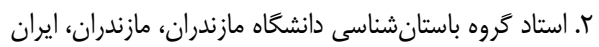

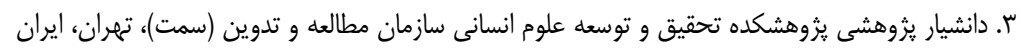

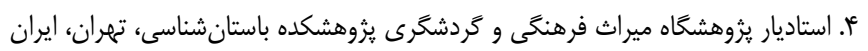

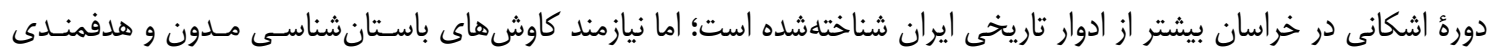

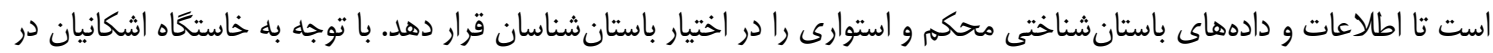

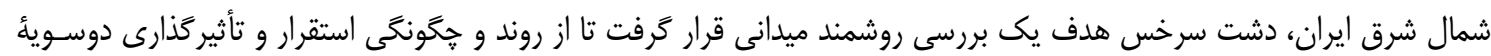

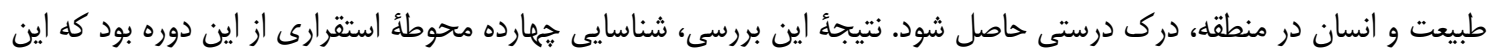

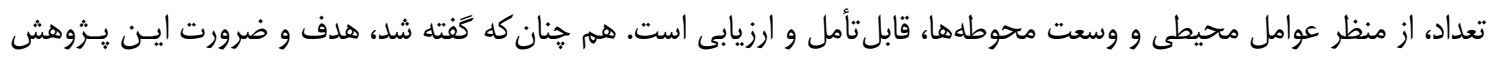

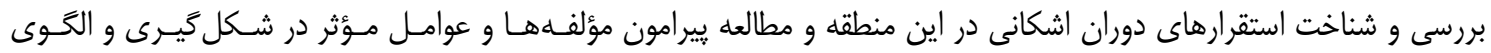

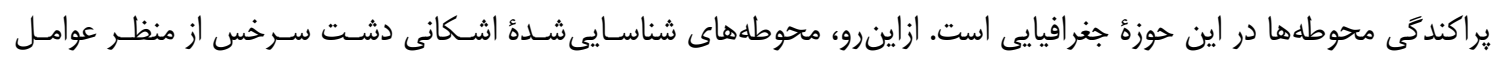

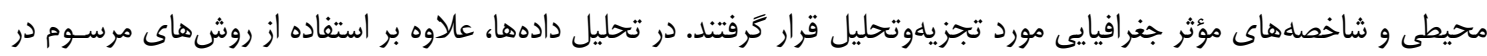

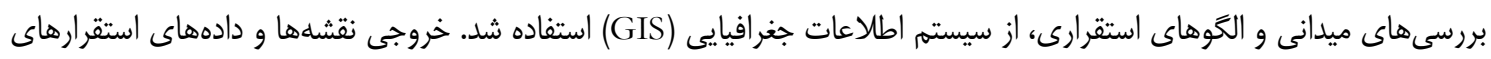

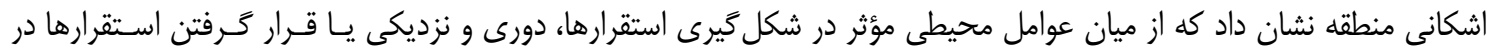

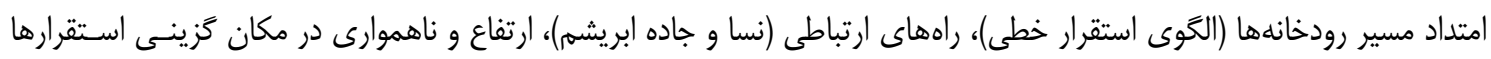

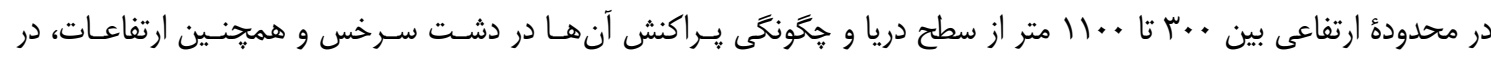

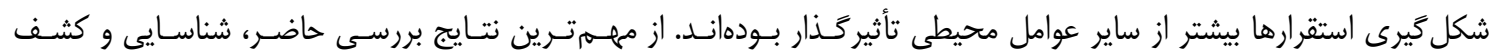

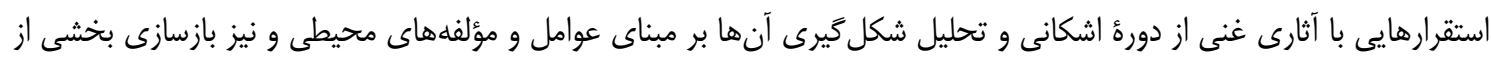

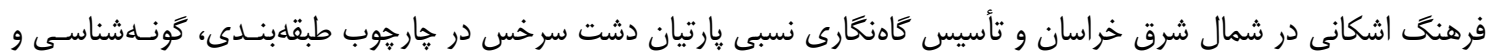

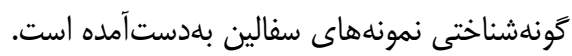

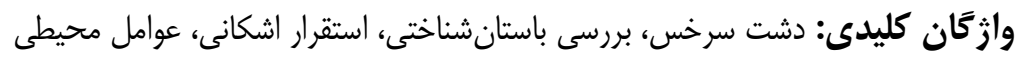

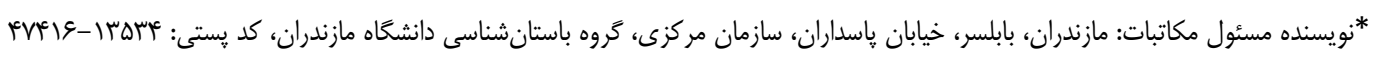
reza.mehrafarin@gmail.com آدرس الكترونيكى، C) حق نشر متعلق به نويسنده(كان) است و نويسنده تحت مجوز Creative Commons Attribution License به مجله اجازه مىدهد مقاله جابٍ شده را با ديخران به اشتراك بحذارد منوط بر اينكه حقوق مؤلف اثر حفظ و و به انتشار اوليه مقاله در اين مجله اشاره شود. 
(شكل گَيرى حكومت اشكانيان) يـس از آخـرين فـاز دورة

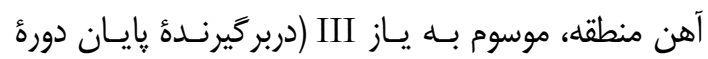

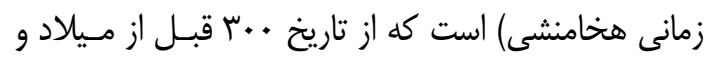

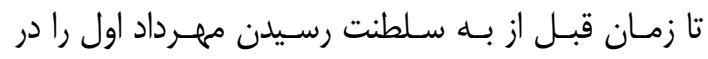

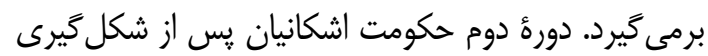

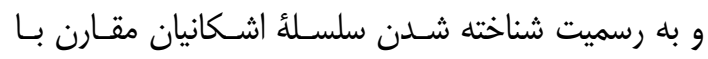

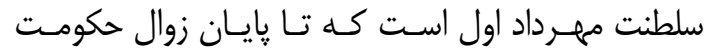
اشكانيان توسط اردشير بابكان ادامه داشـته اسـتـ انجـام

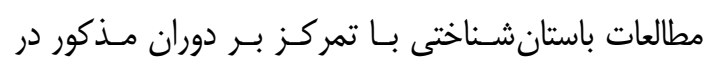

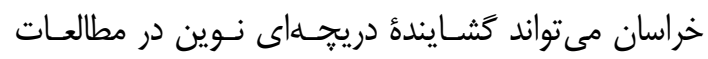

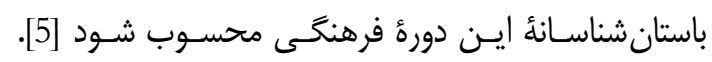

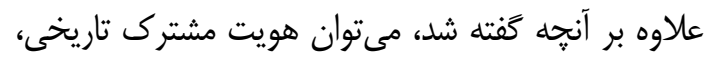

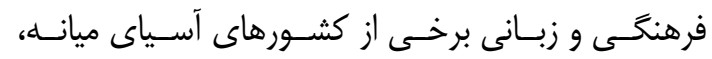

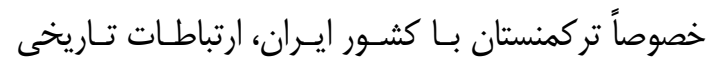

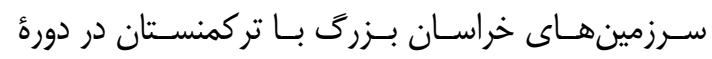

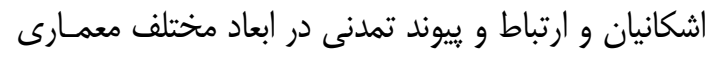

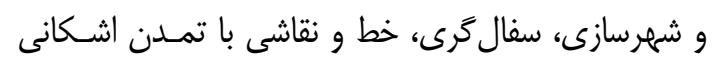

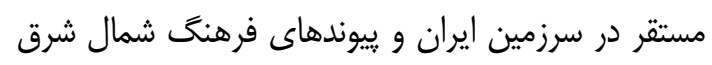

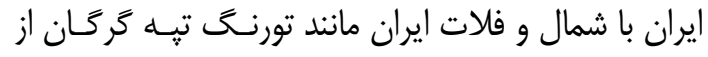

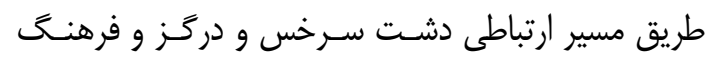

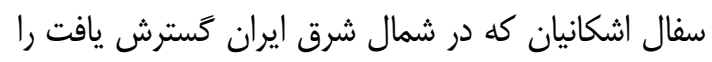

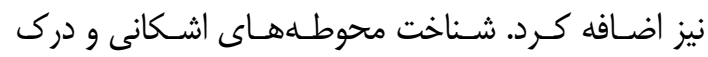

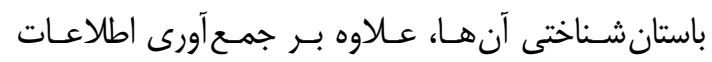

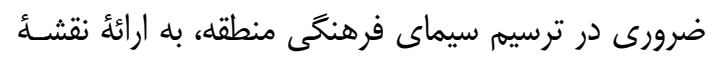

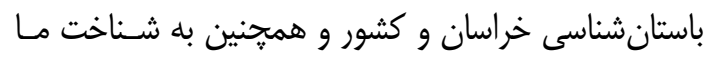

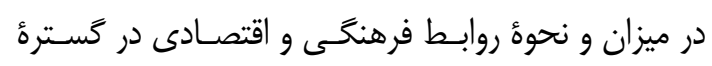

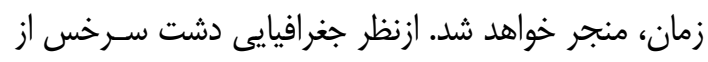
سمت جنوب غرب به مشهد راه ارتباطى و مواصلاتى دارد

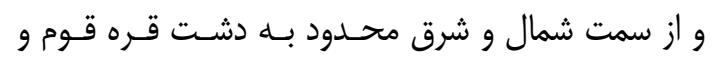

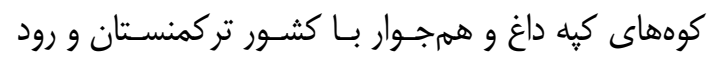

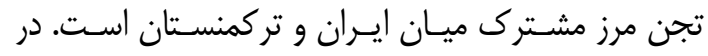

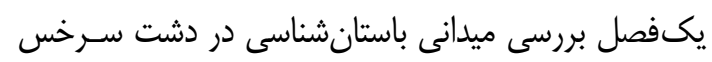

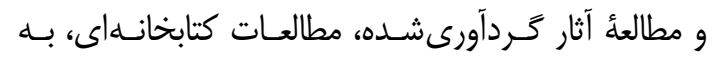

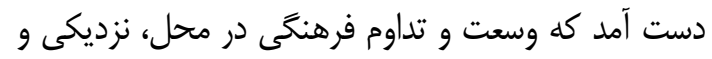

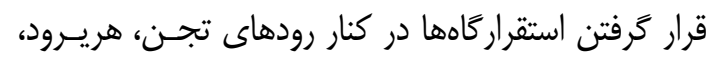
كشفرود و شورلوق در تمام جهات جغرافيايى موردمطالعه
(. - مقدمه

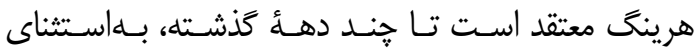
اطلاعات مبهم تاريخى، شناخت دوره اشكانى منحصر بــهـ

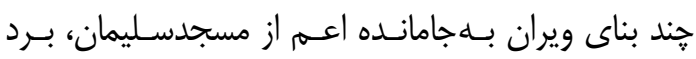

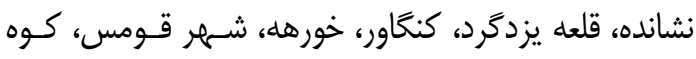
خواجه و نقش برجستههاى اليمايى در جنوب غرب ايـران

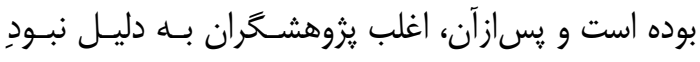
منابع و مدارى كافى، مطالعات تخصصى ايسن دوره را نيـز

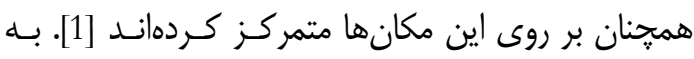

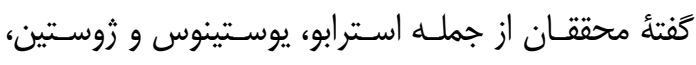

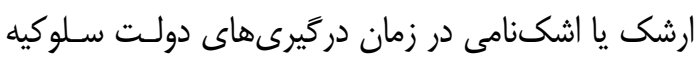

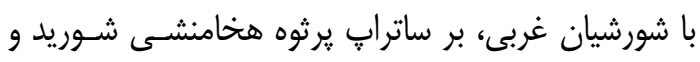

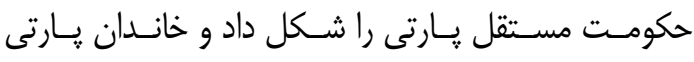

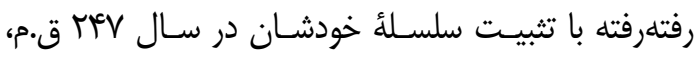

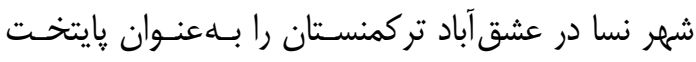

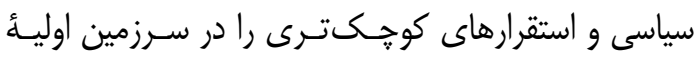

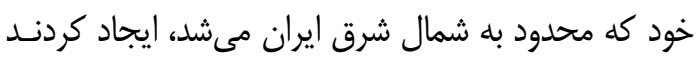
[2]. دشت سرخس در شـمال شـرق ايـران بــه دليـل دارا

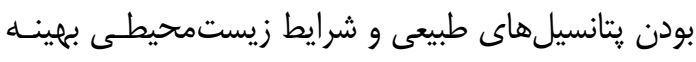
ازجمله ارتفاعـات، خـاك مناسـب و اوضـاع جـوى نســــاً مساعد، زيستخاه مطلـوبى بــراى شـكل گكيـرى اجتماعـات مختلف انسانى بوده است، ازاينرو منطقة مذكور از بهترين

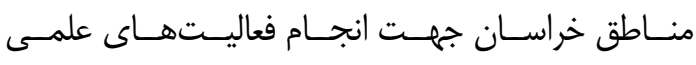
باستان شناسى است [3]. دانستههاى ما از ايـن منطقـه در

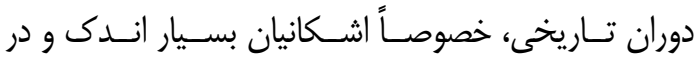
بسيارى موارد فاقد هر گونه مدارى باستانشــاختى اسـتـ

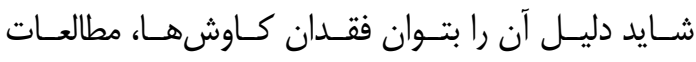

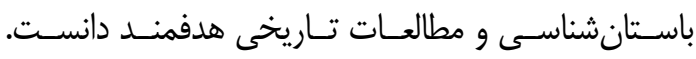

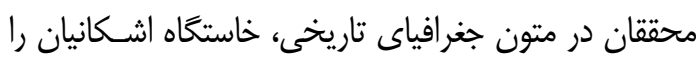

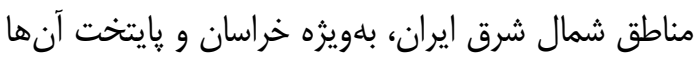

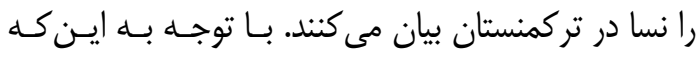

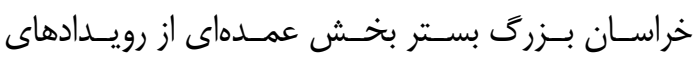

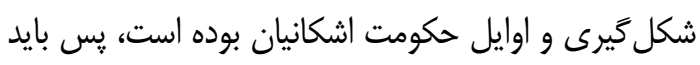
در مطالعات دورة اشكانى، سرزمين خراسان اين دوره را به دو زير دوره الف: دوره شكل گيـرى حكومـت اشـكانيان و ب: دوره حكومت اشـكانيان، تقسـيهم كـرد [4]. دورة اول 
مزدوران به مركزيت روستاى مزدوران شامل دهستانهاى

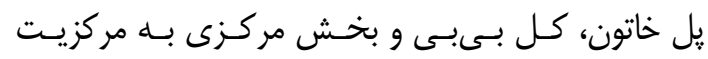

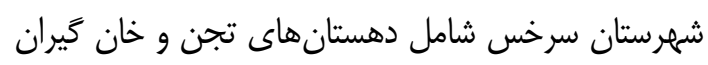

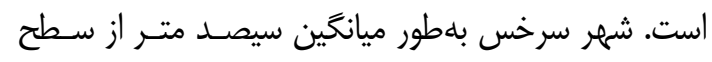

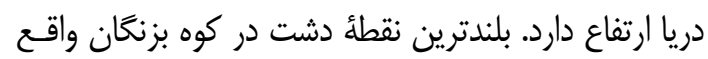

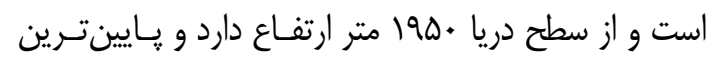

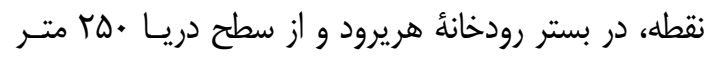

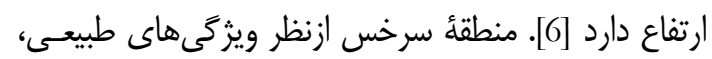

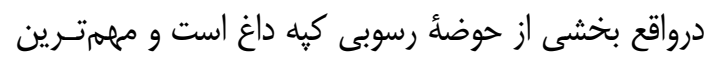

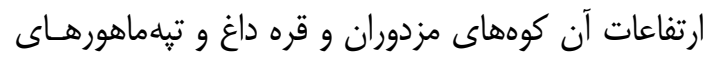

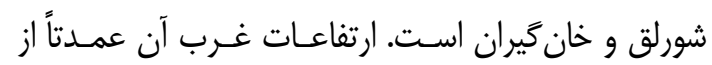
سنخهاى رسوبى دوران دوم و سوم زمين شناسى تشكيل

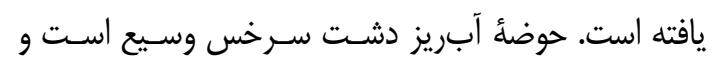

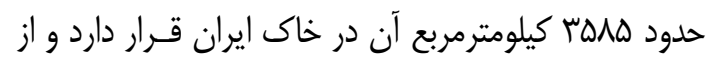

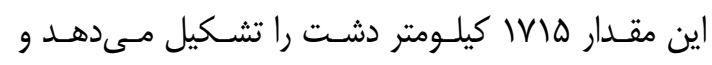

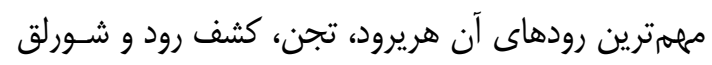

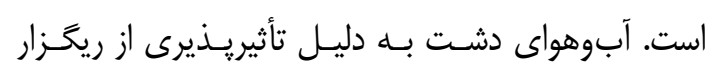

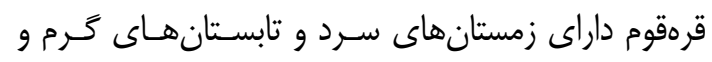
خشك است [7].

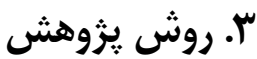

يروهش حاضر بر اساس هدف، از نوع تحقيقات بنيـادى و

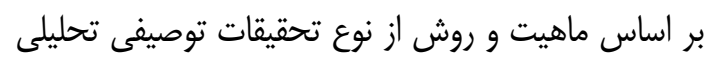

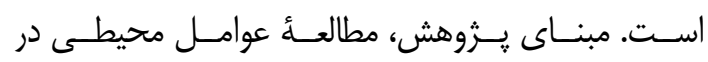

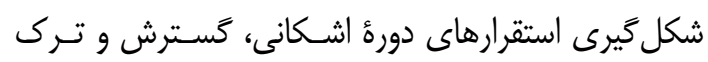

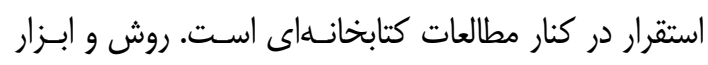

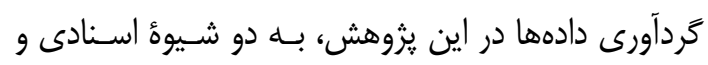

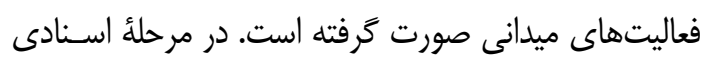

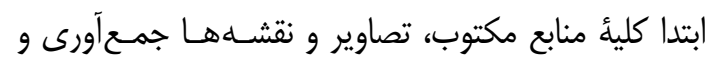

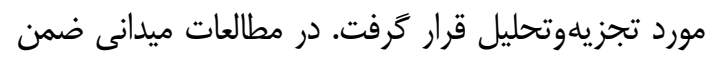

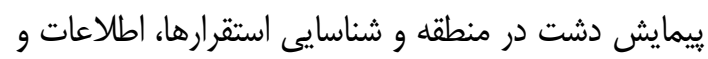

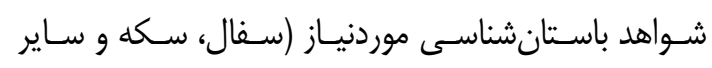

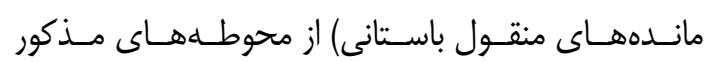

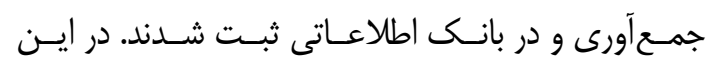

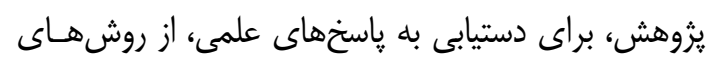

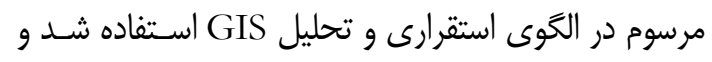

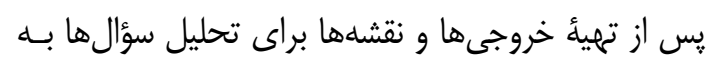

در دشت سرخس، حاكى از اين است كه اين منطقه يــ

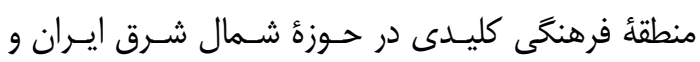

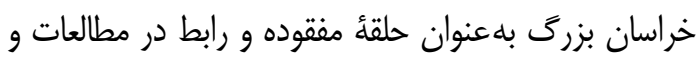

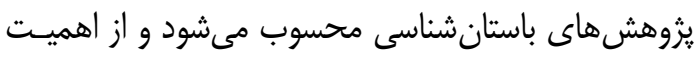

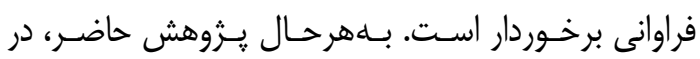

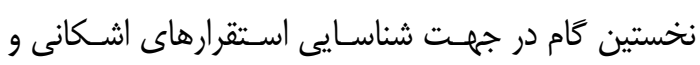

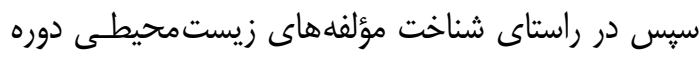

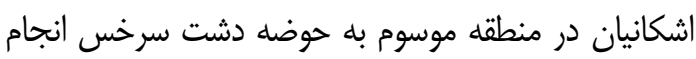

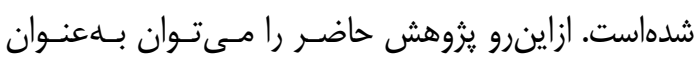

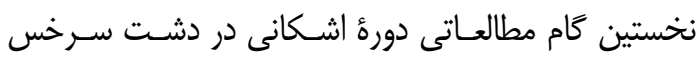

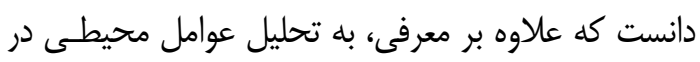

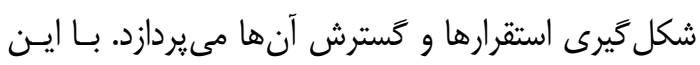

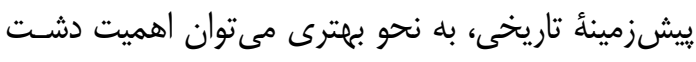

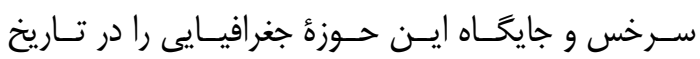

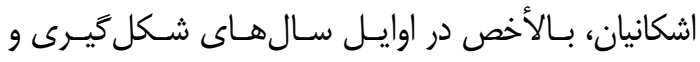

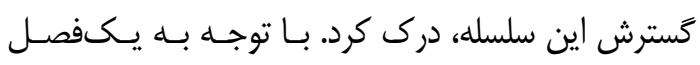

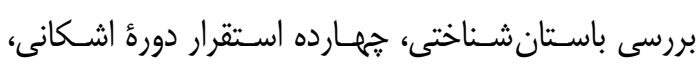

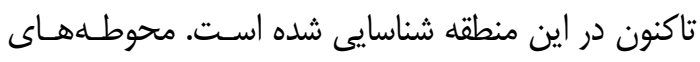

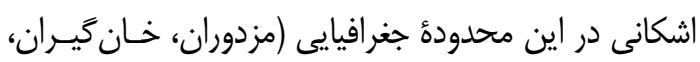

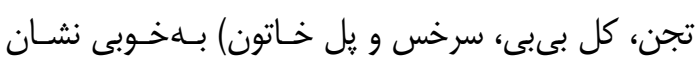

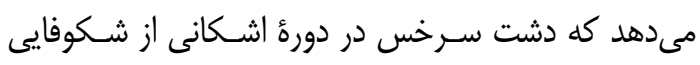

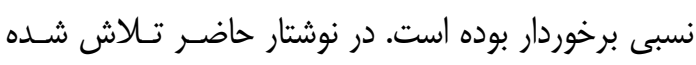

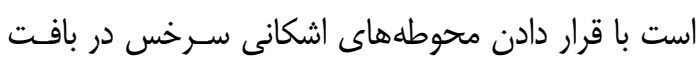

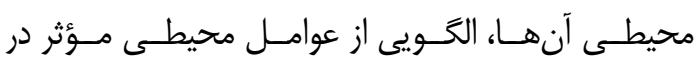
شكل گَيرى و يراكندگى محوطه نهاى اشكانى به دست آيد.

\section{r. موقعيت دشت سرخس}

شهرستان سرخس در شمال شرق ايران به وسعت تقريبى

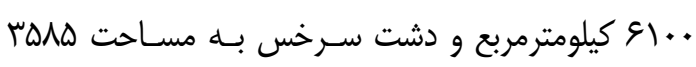
كيلومترمربع در منتهى اليه شمال شـرقى اسـتان خراسـان

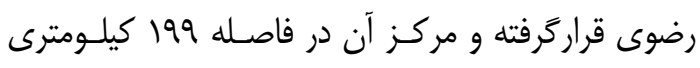

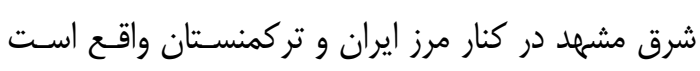

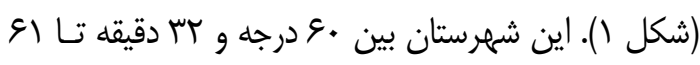

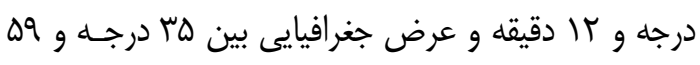

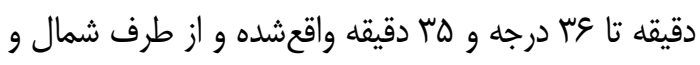

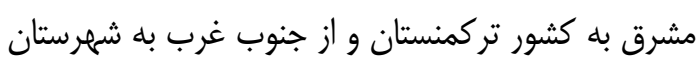

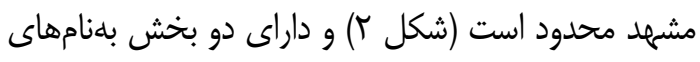


بهروزىفر و همكاران / ارزيابى عوامل محيطى در شكليَرى استقرارهاى اشكانى دشت سرخس

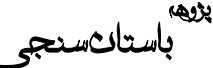

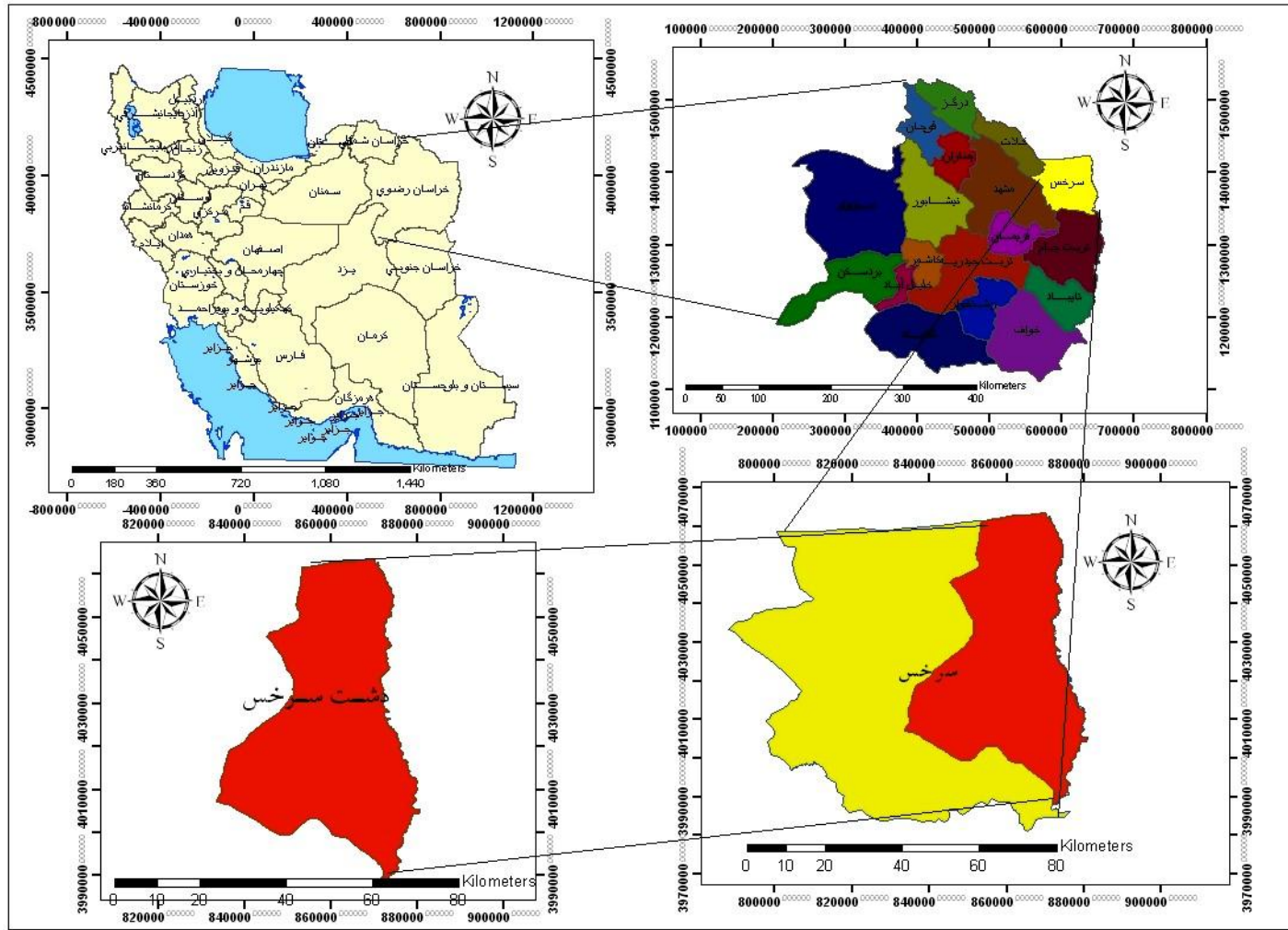

شكل (:موقعيت دشت سرخس

Fig. 1: Location of Sarakhs plain

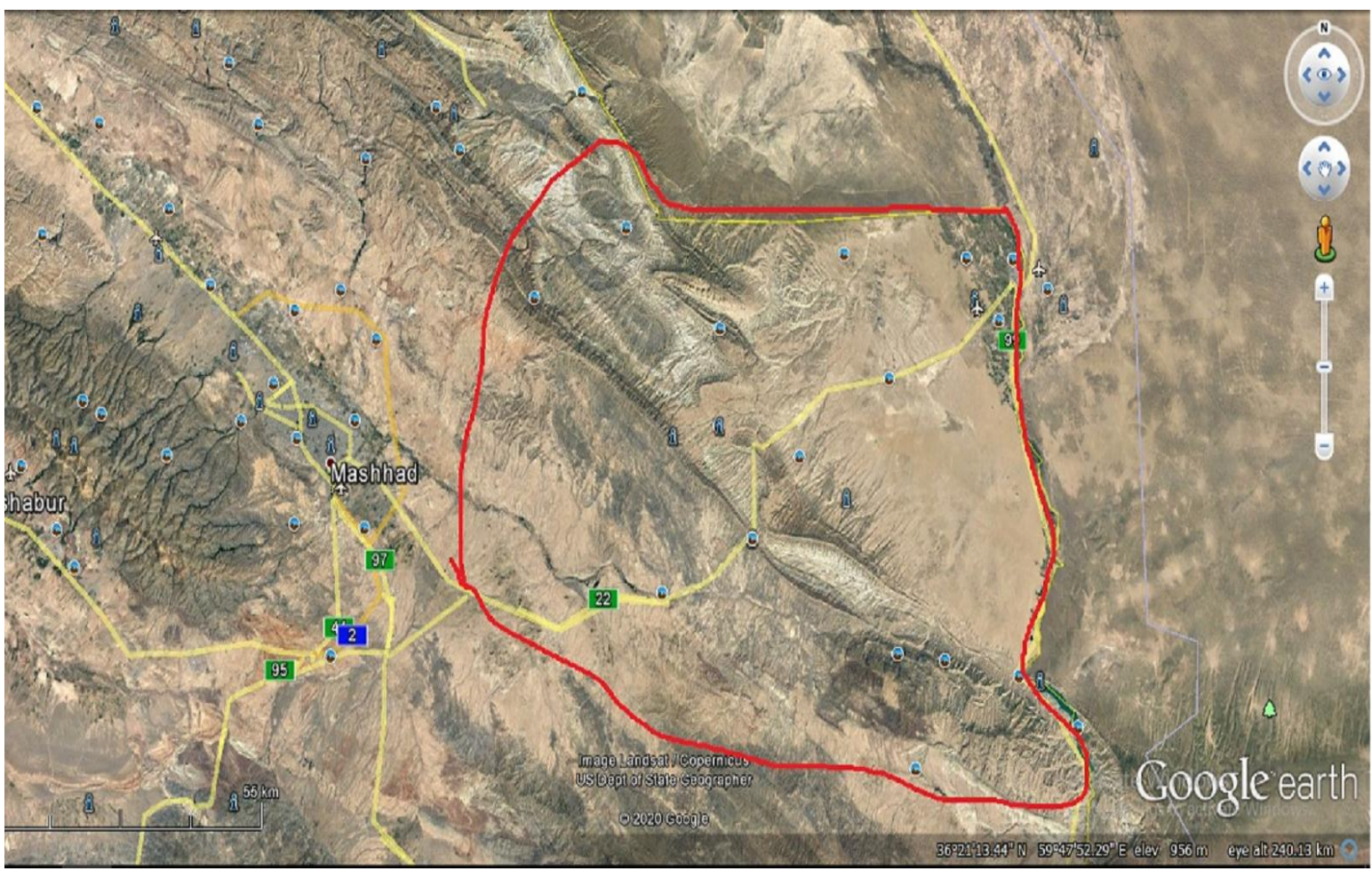

شكل r: محدودة ماهوارواى دشت سرخس (Google Earth)

Fig. 2: Satellite area of Sarakhs plain (Google Earth)

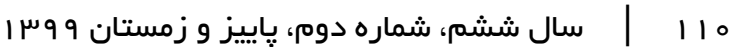


ساختار زمينشناختى و بسترهاى محيطى يك زمين سيما

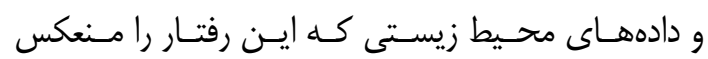

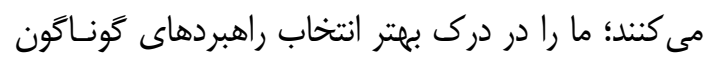

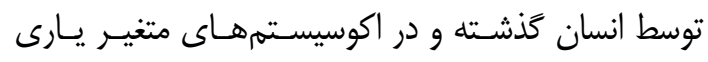

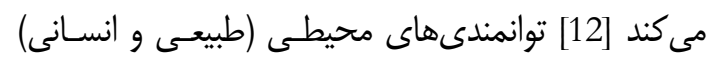

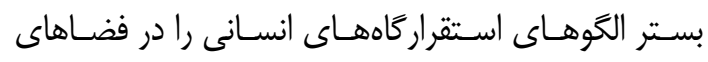

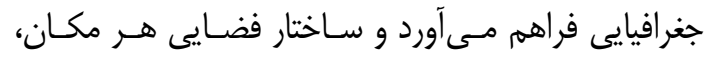

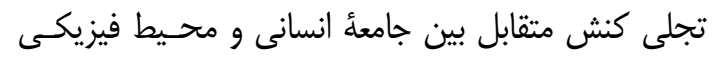

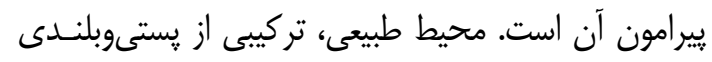

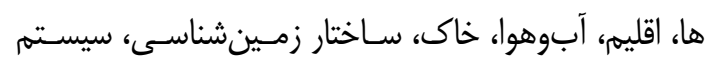

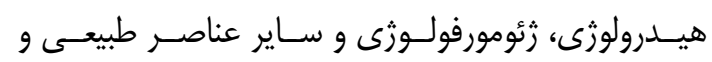

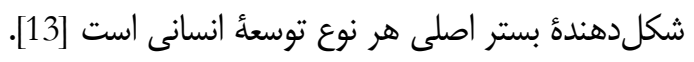

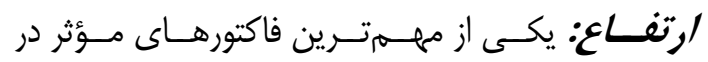

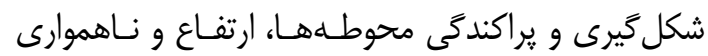
است. محوطههاى باستانى، بسته به اهداف ساخت آنهاء

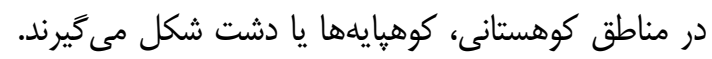

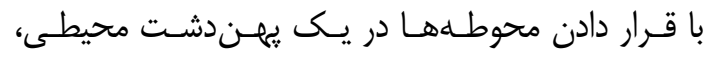

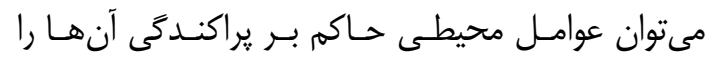

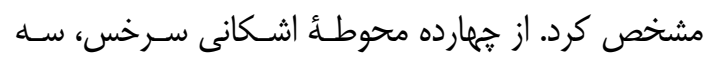
محوطه با ارتفاع بيش از ..9 تا ...11 متر و سه محوطهـ

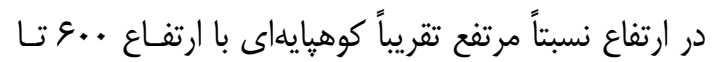
A متر و هشت محوطه در دشت در ارتفاع كمتر از ... . .

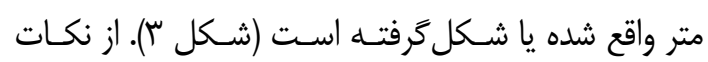

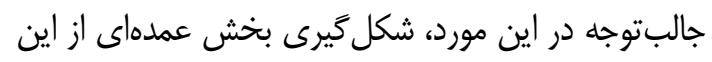

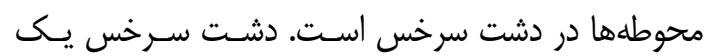
دشت ميان كوهى است؛ بنابراين انتظار وجود محوطههاى تاريخى در مناطق مرتفع ايسن شهرسـتان، خصوصـاً تنهـا

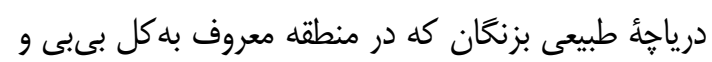

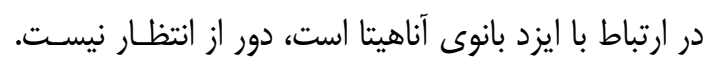

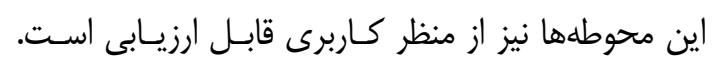

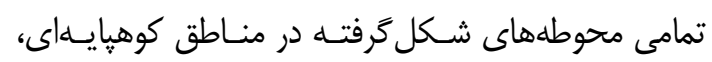

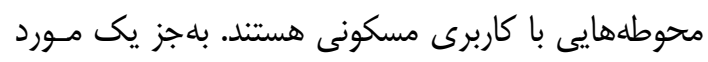

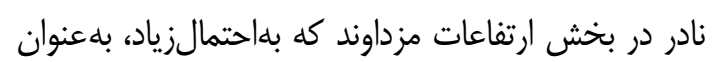

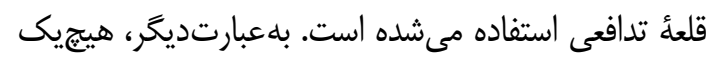

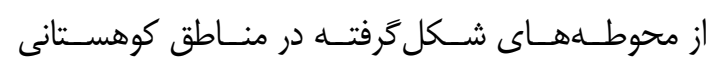

دو روش توصيفى و استباطى عمل شد. درروش توصـيفى

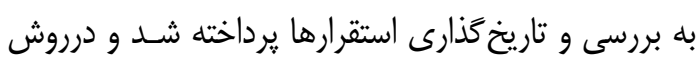

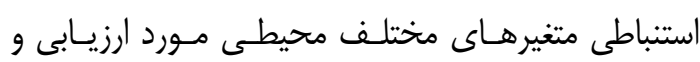

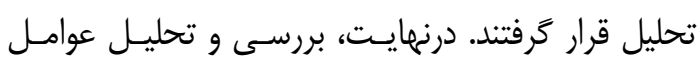

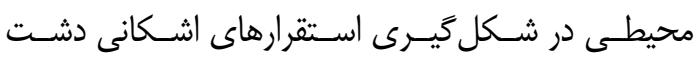

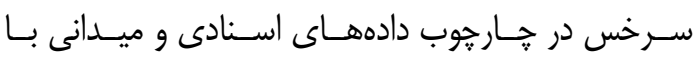
بهره كيرى از خروجى نقشهها صورت بذيرفت.

\section{ع. مؤلفههاى محيطى در شكلَيرى و يراكندكى استقر ارهاى دشت سرخس درس}

نتيجأ يكفصل بررسى ميدانى در دشت سرخس منجر بـ است

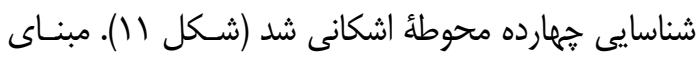

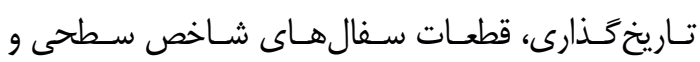

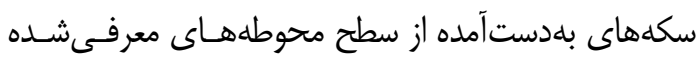

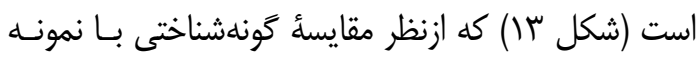

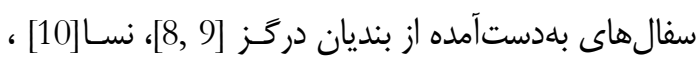

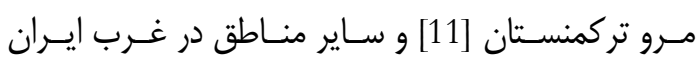

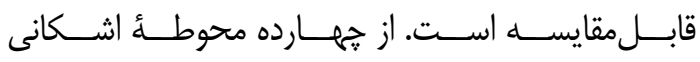
شناسايىشده، ينج محوطه در بخش سرخس، سه محوطه

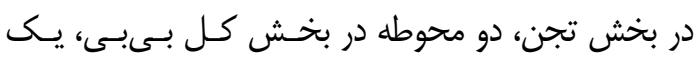

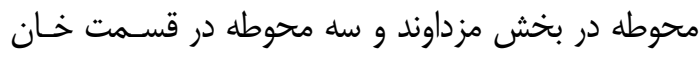

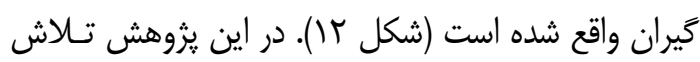

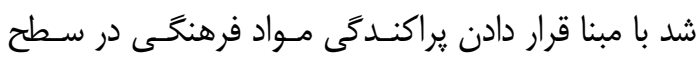

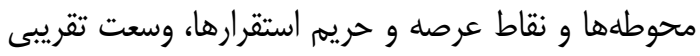

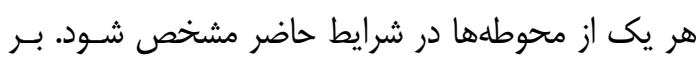

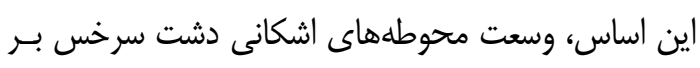

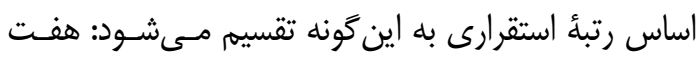

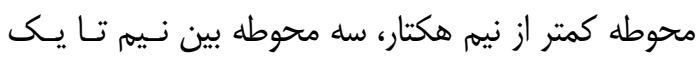
هكتار و جهار محوطه بـين يـك تـا يـك و نسيمه هكتـار.

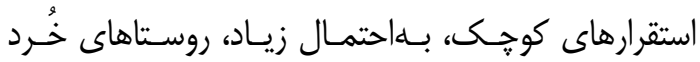

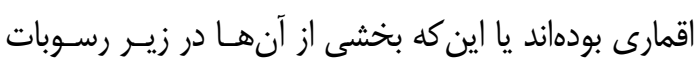

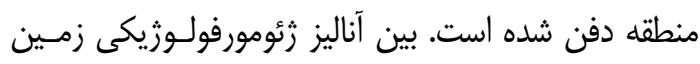

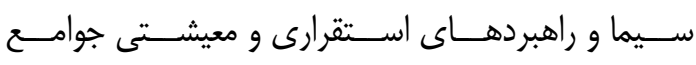

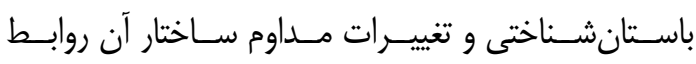

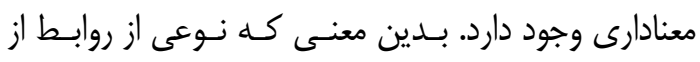

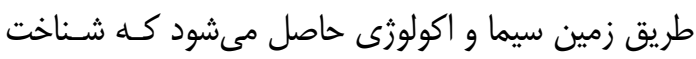



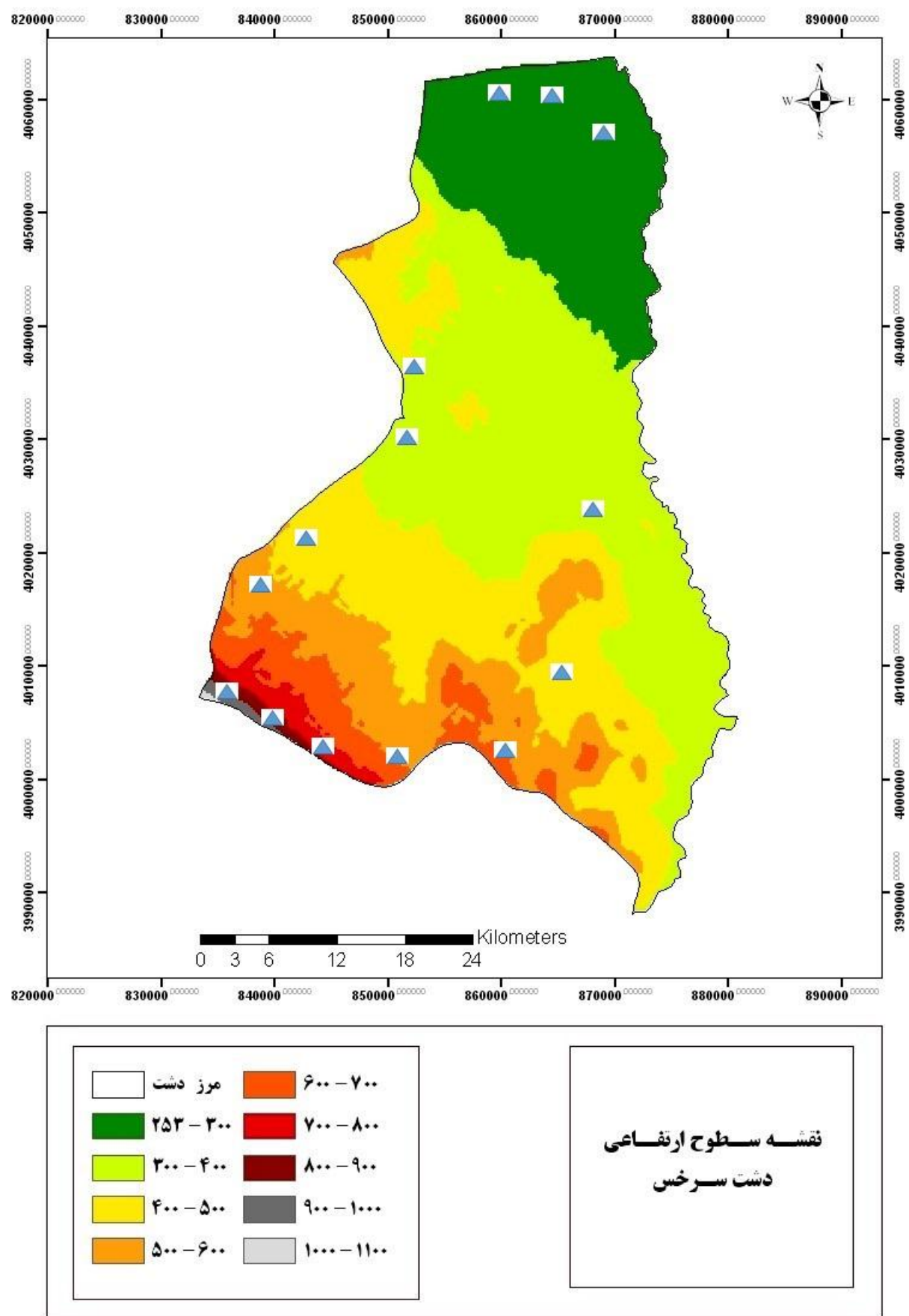

شكل ":: تغييرات ارتفاعى دشت سرخس و مكان محوطهها نسبت به آن [14]

Fig. 3: Elevation changes of Sarakhs plain and the location of yards relative to it [14]

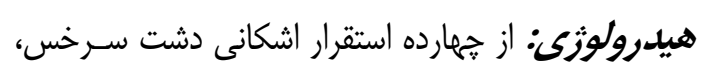

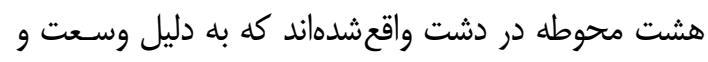

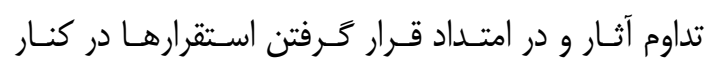

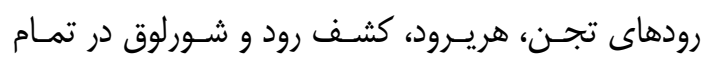

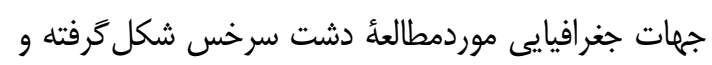

شهرستان سرخس كاربرى نظامى نداشتهاند. اين مورد

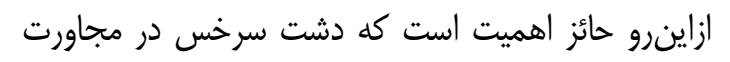

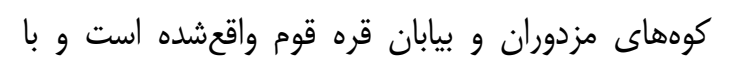

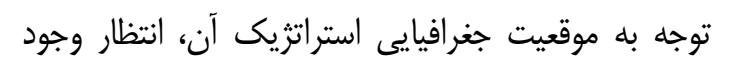
اين طيف محوطهها، منطقى به نظر مىرسد.

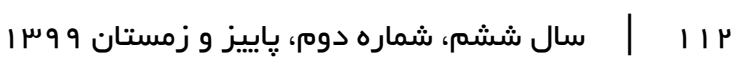


راههايى ارتباطى: در مبحث عوامل مؤثر در شكل

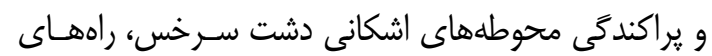

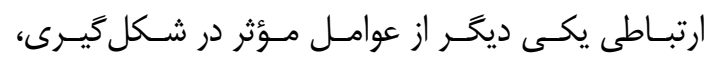

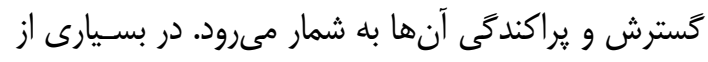

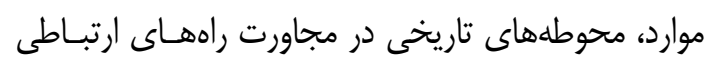

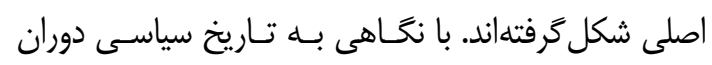

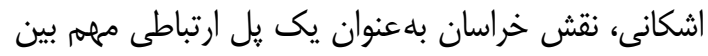

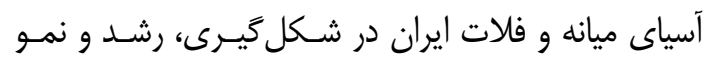

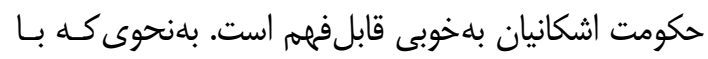

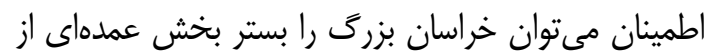

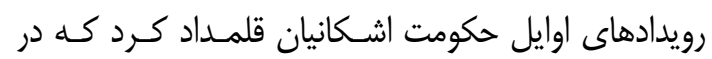

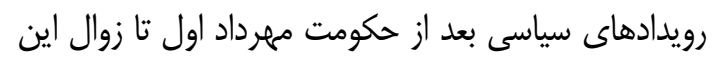

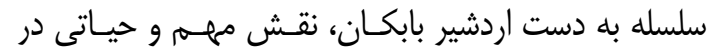

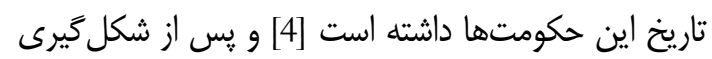

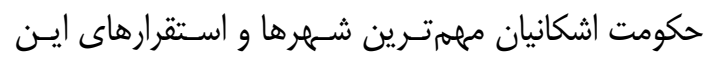
دوره در منــاطق دشـت ســرخس، دركَّز، مـرو و نســا در

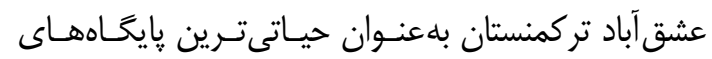

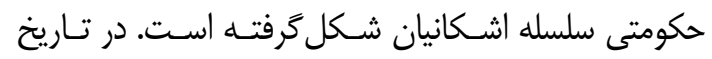

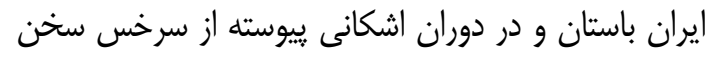

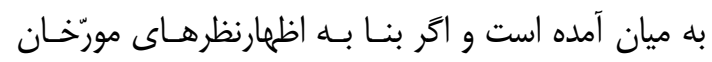
معتقد باشيم كه فردوسى، مآخذى از تاريخ ايران شرقى در النها

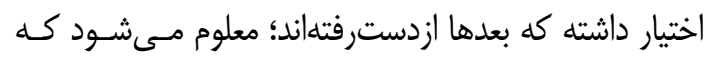

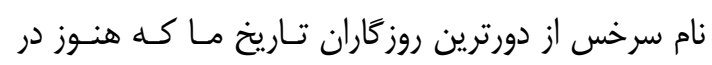
نقاب تاريكى مانده، وجود داشته است [16]. ازنظر موقعيت مكانى نيز بر ما روشن است كـه ايـن دشـت، همـواره در

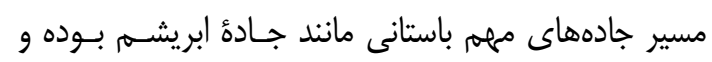

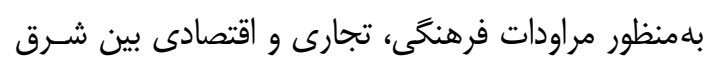
و غرب اهميت زيادى داشته است. راههاى ارتباطى شمال

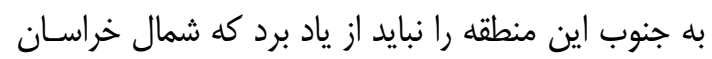

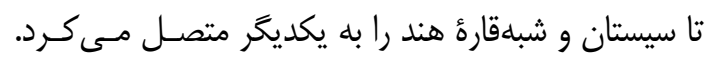

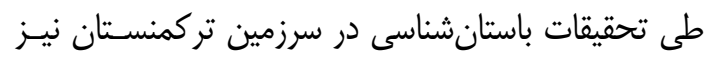

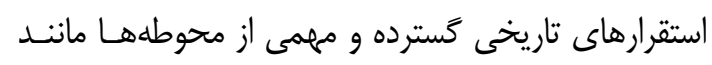

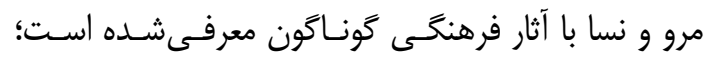

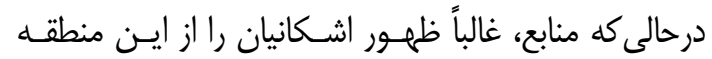

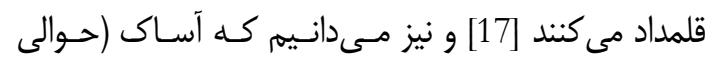

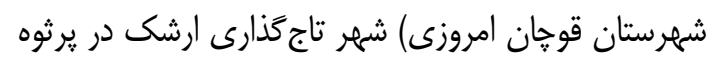

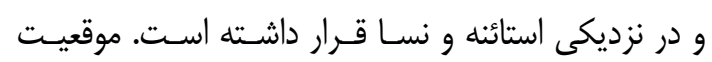

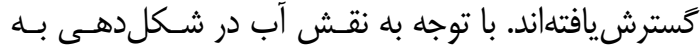

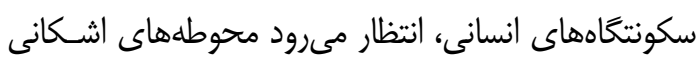

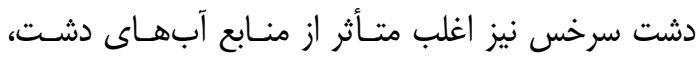

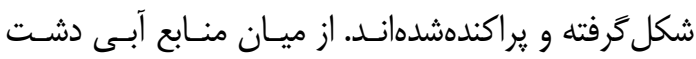
سرخس، محوطههاى اشكانى اين منطقه از منظر نزديكى

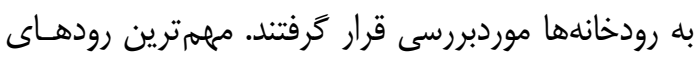
دشت سرخس به شرح زير اسـت: ا-مرودخانــ هريـرود: از

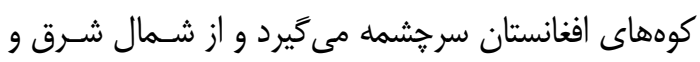

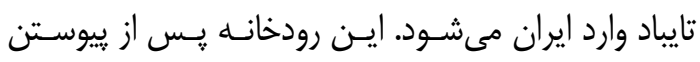

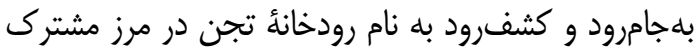

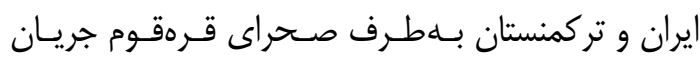

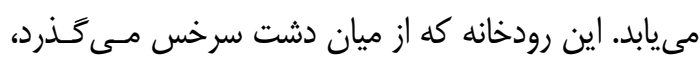

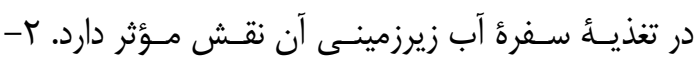

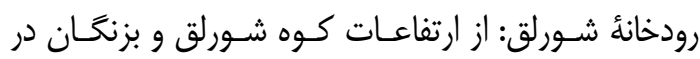

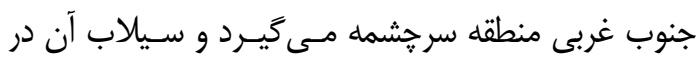

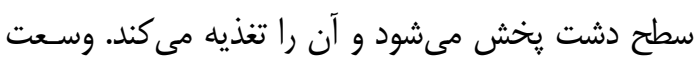

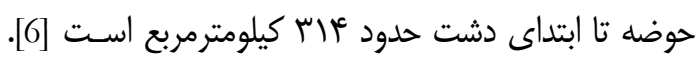

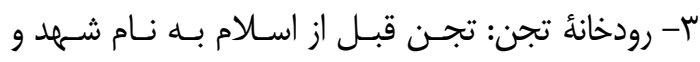

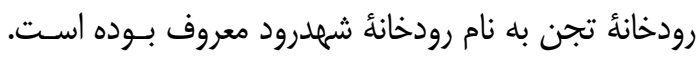

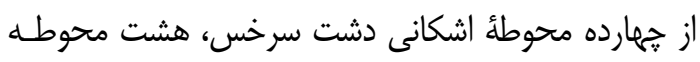

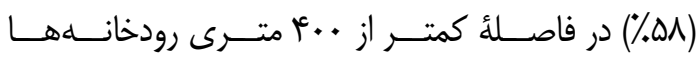

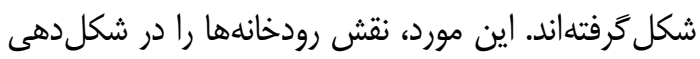

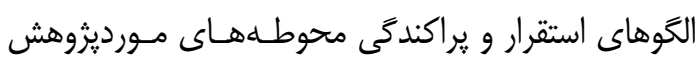

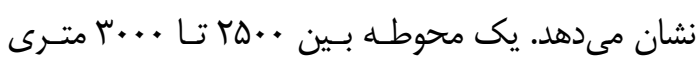

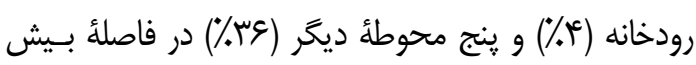

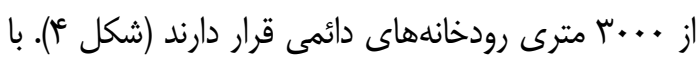

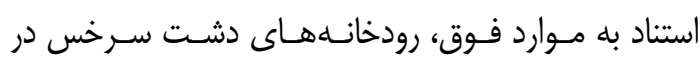

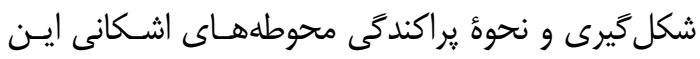

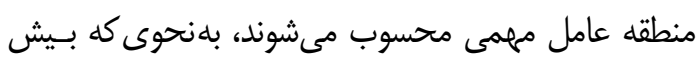

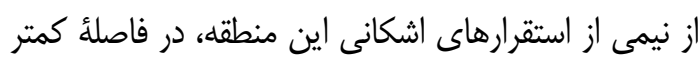

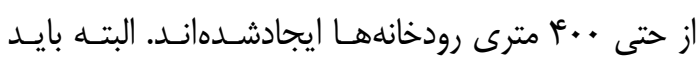

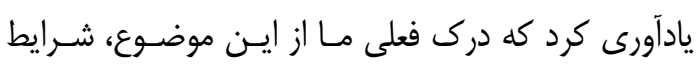

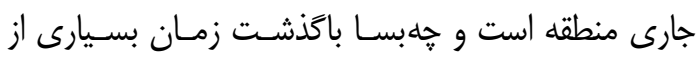

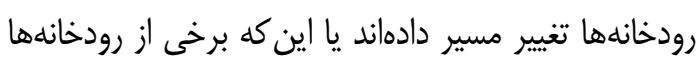

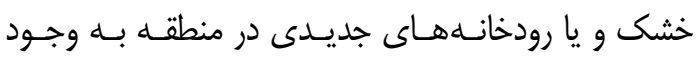

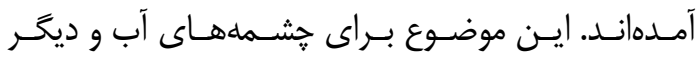
مؤلفهاى هيدرولوزى نيز صادق است.

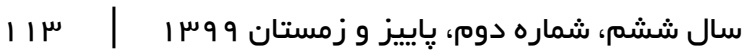



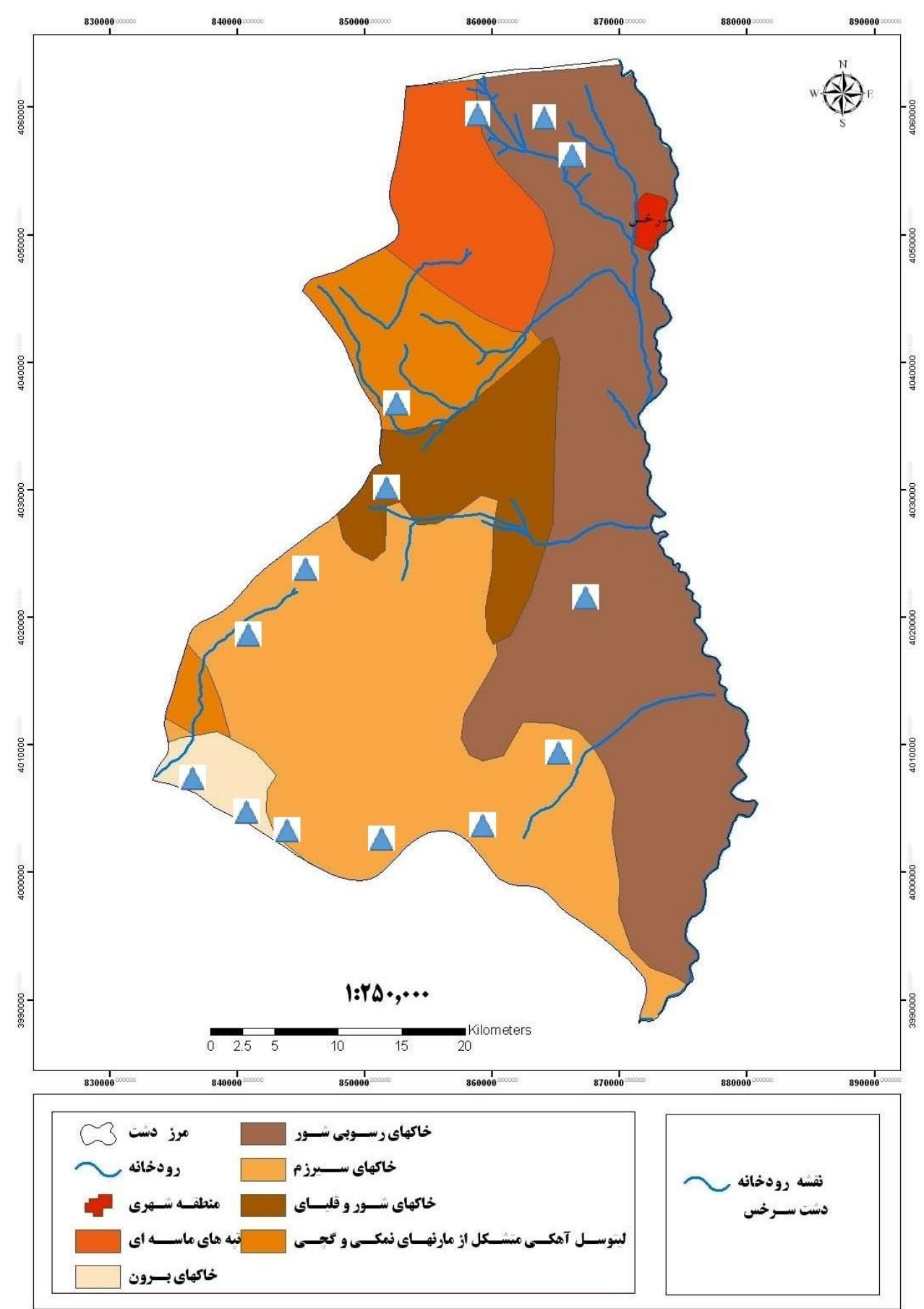

شكل f: موقعيت قراركاهها نسبت به فاصله از رودخانهاى دشت سرخس [15]

Fig. 4: Location of settlements relative to the distance from the rivers of Sarakhs plain [15]

محافل علمى دنيا در تر كمنسـتان درعـينحسال وابستختى

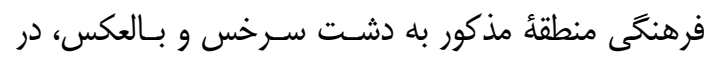

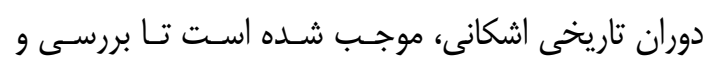

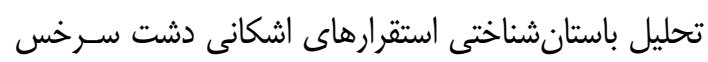

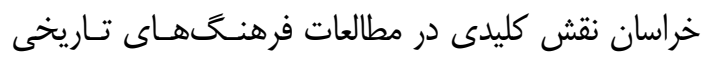

جغر افيايى ويزٔه دشت سرخس، به خصوص واقع شـدن آن در بين حوزههاى فرهنكى فلات ايران و آسياى مركـزى

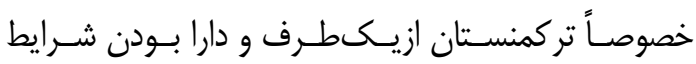

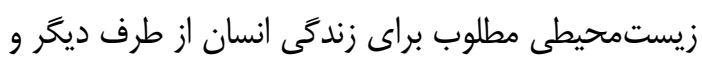

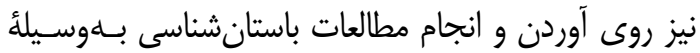

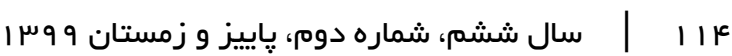


زئومورفولوزئ: از مؤلفهاى ديكر مىتوان بـهـ شـكل

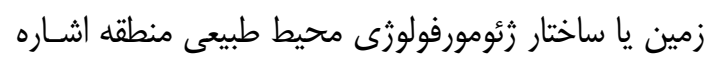

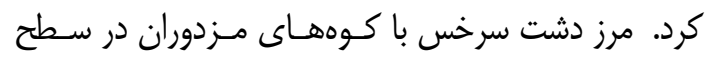

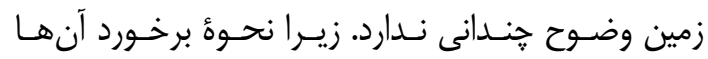

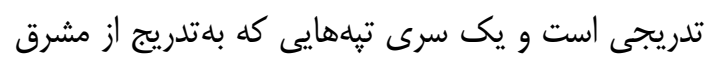

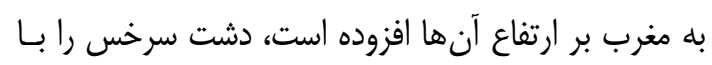

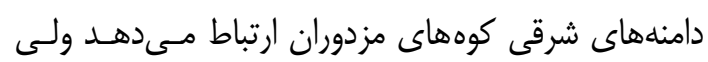

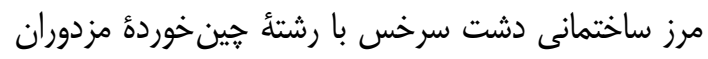

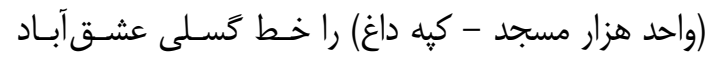

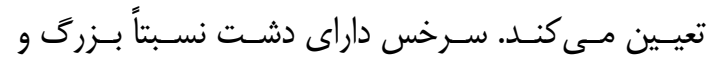

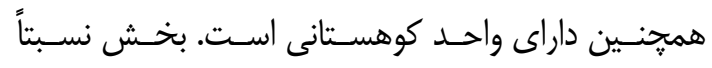

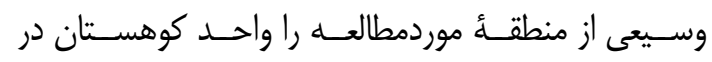

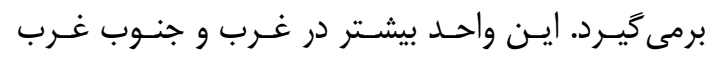

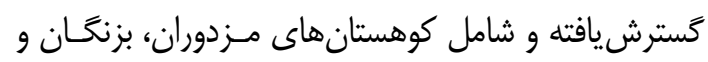

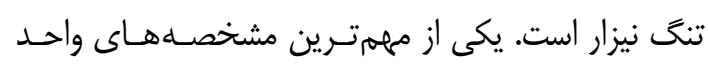

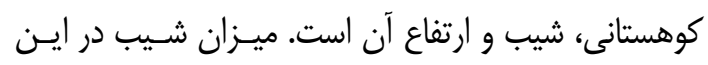

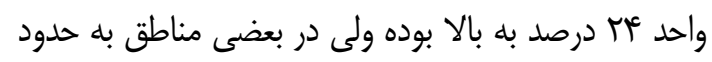

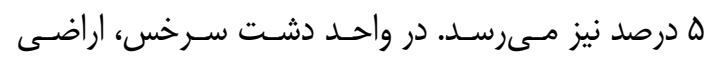

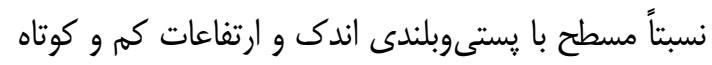

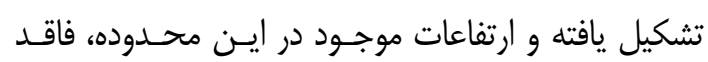

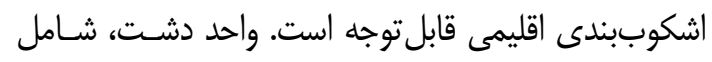

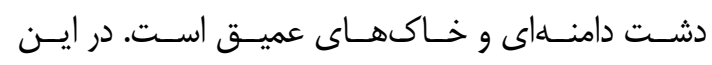

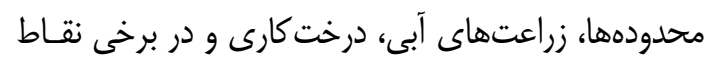

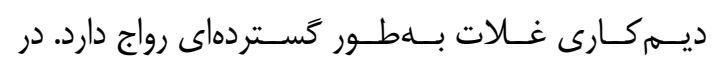

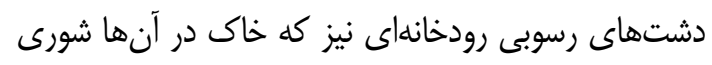

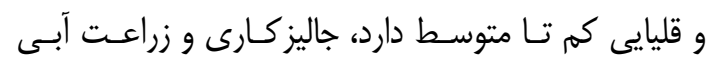

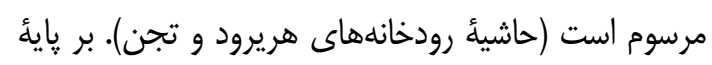

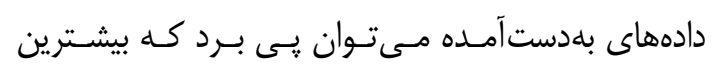

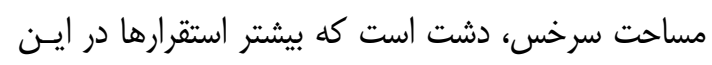

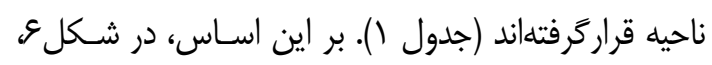

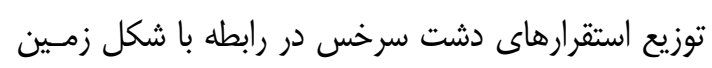

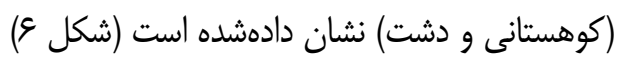

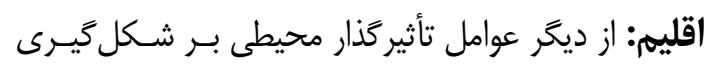

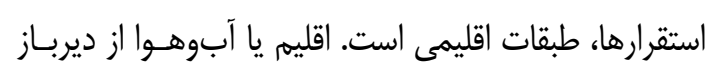

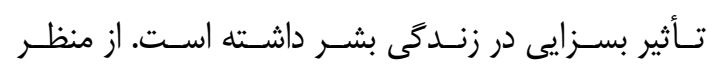

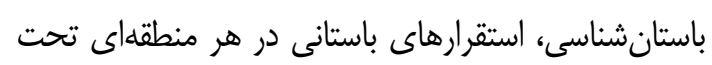

بلهور عام، شمال شرق ايران و تركمنستان بلهطور خـاص

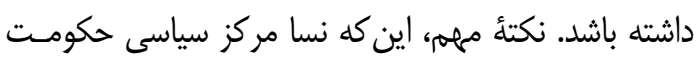

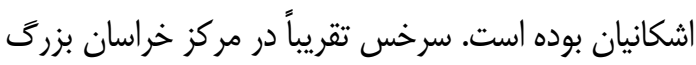

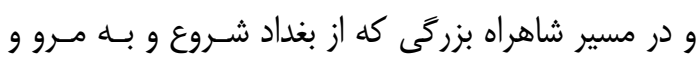

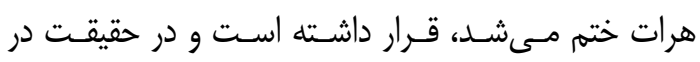

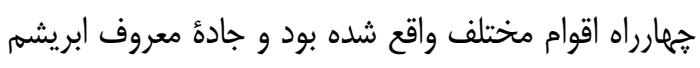

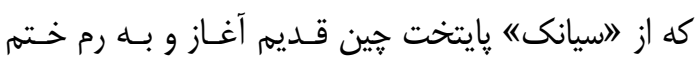

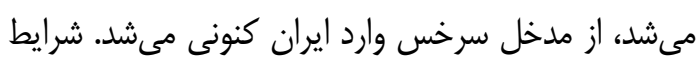

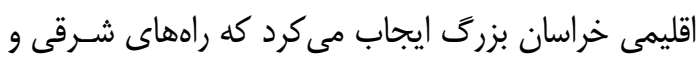

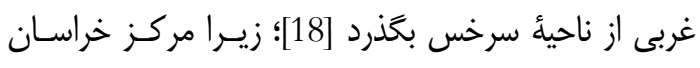

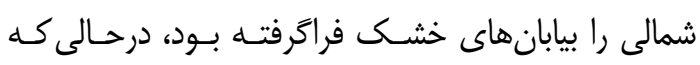

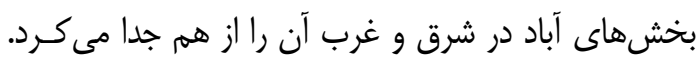

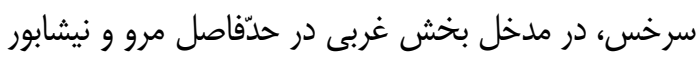

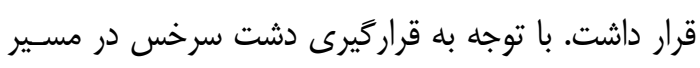

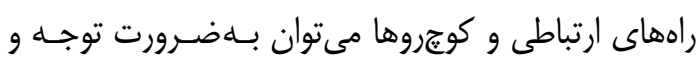

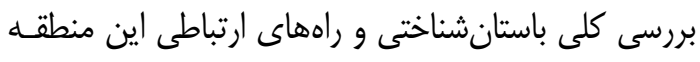

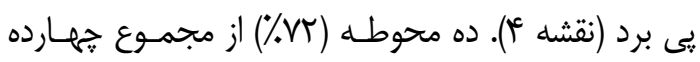

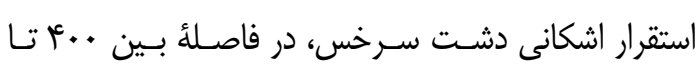

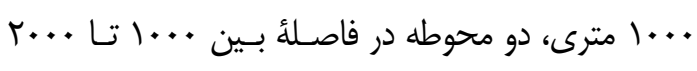

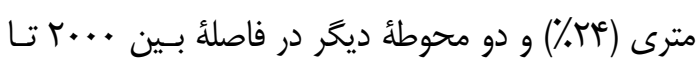

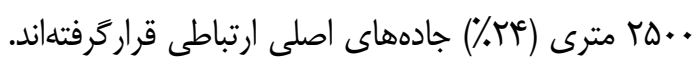

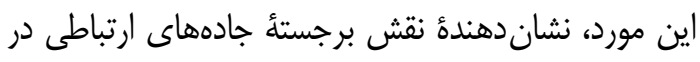

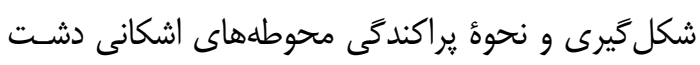

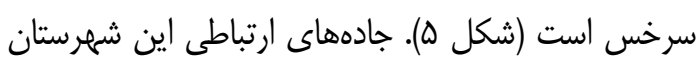

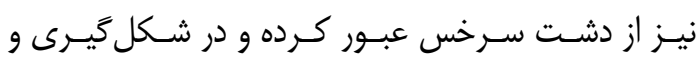

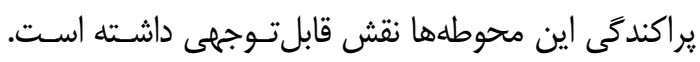

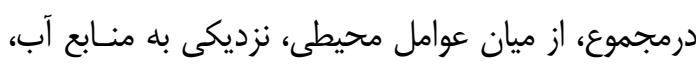

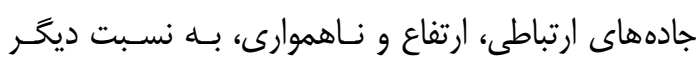

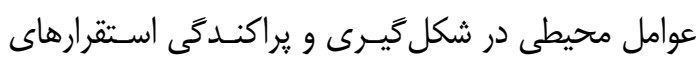

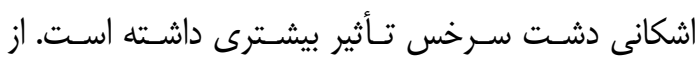

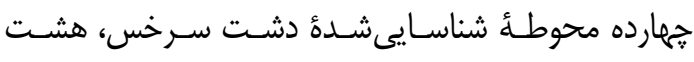

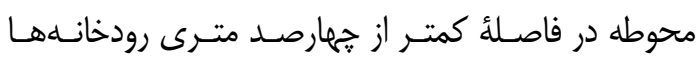

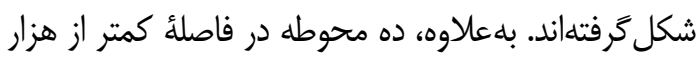

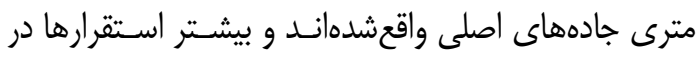
بخش دشت سرخس و كمتر از ششصد متر از سطح دريـا

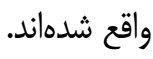



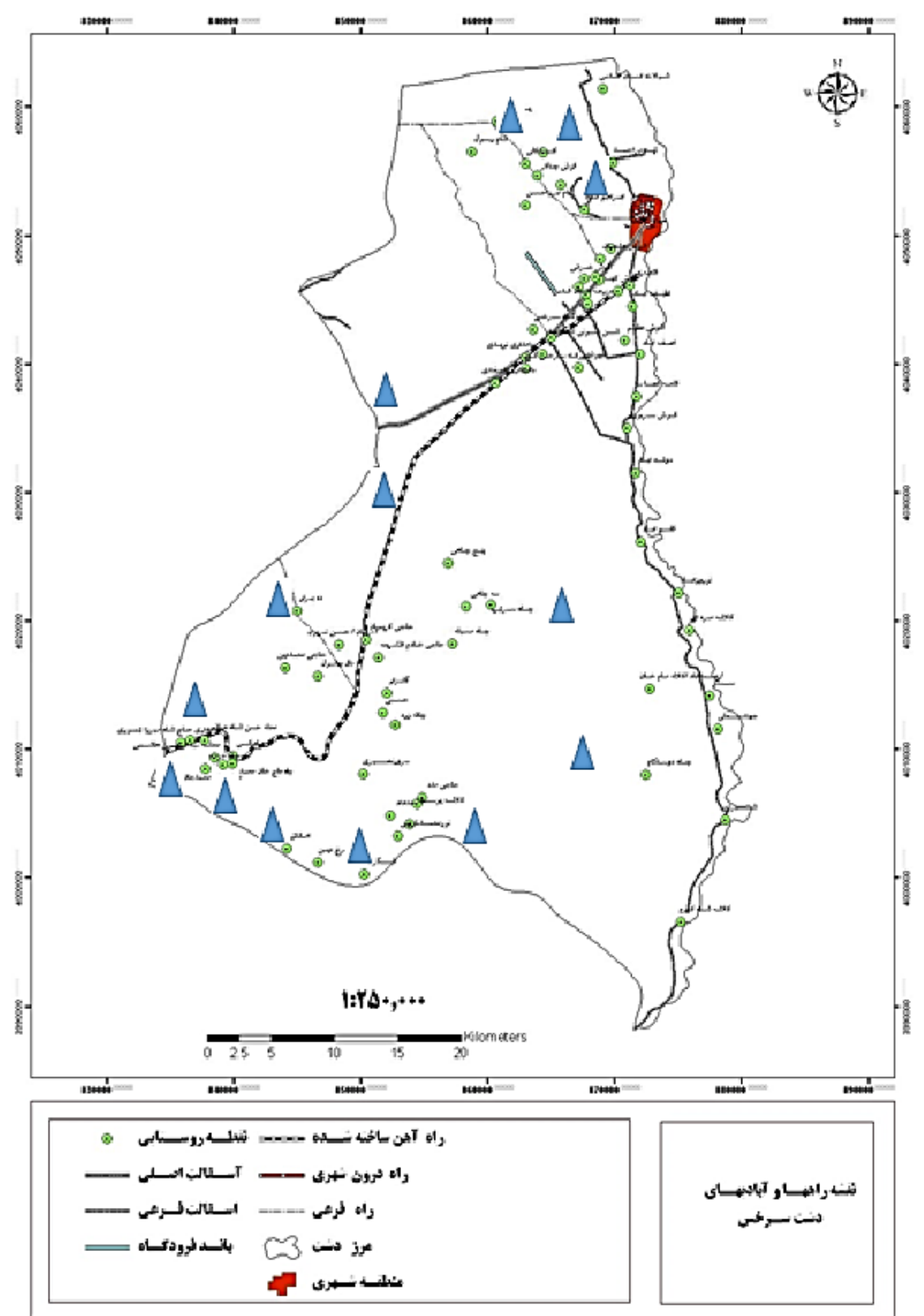

شكل ه: موقعيت استقرارها نسبت به فاصله از راههاى ارتباطى [14]

Fig. 5: Position of deployments relative to distance from communication routes [14]

$$
\text { جدول ا: جدول توزيع استقرارها در مناطق دشتى و كوهستانى }
$$

Table 1: Distribution table of settlements in plain and mountainous areas

\begin{tabular}{|c|c|c|c|c|}
\hline $\begin{array}{l}\text { Percent } \\
\text { Pرصد }\end{array}$ & $\begin{array}{l}\text { تعداد استقرارها } \\
\text { Number of } \\
\text { deployments }\end{array}$ & $\begin{array}{c}\text { درصد } \\
\text { Percent }\end{array}$ & $\begin{array}{c}\text { مساحت (كيلومترمربع) } \\
\text { Area (square kilometers) }\end{array}$ & شكل زمين \\
\hline 72 & 10 & 86 & 3090 & $\begin{array}{l}\text { دain } \\
\text { Plain } \\
\end{array}$ \\
\hline 28 & 4 & 14 & 490 & $\begin{array}{c}\text { كوهستان } \\
\text { mountain }\end{array}$ \\
\hline
\end{tabular}




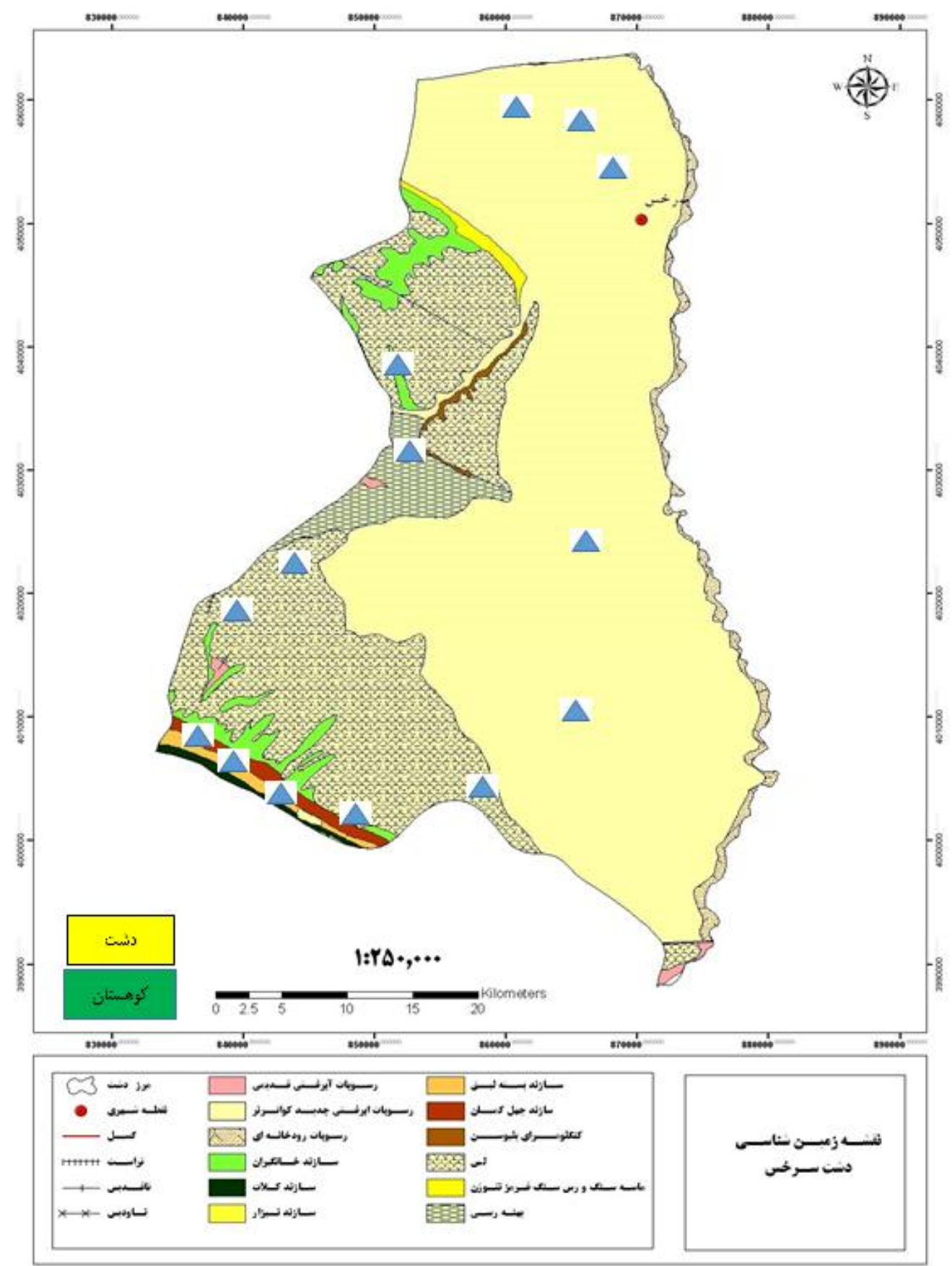

شكل \&. موقعيت استقرارها در مناطق كوهستان و دشت [19]

Fig. 6: Location of settlements in mountainous and plain areas [19]

آبوهوايى خشك است كه در تابستانها، كرماى آن بـانهـ

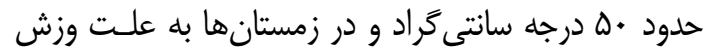

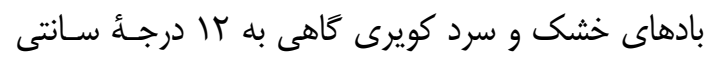

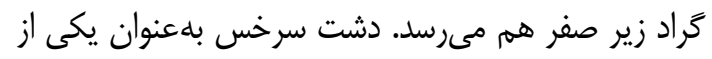

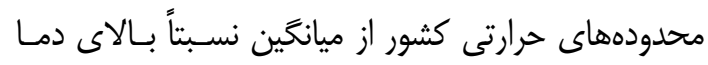

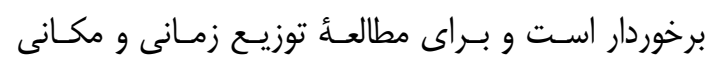

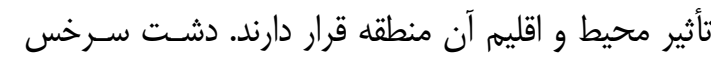

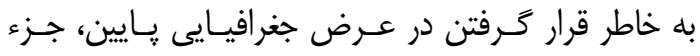
شهر ستانهاى كرم كشور به شمار مى آيد. ارتفاع كم ناحيئ

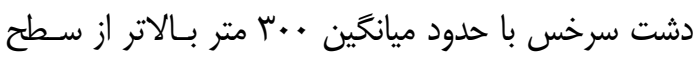

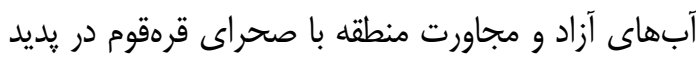

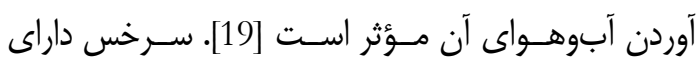

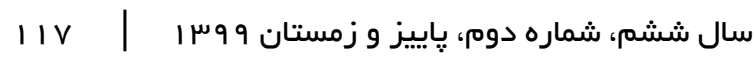


جدول r: توزيع استقرارها در طبقات اقليمى مختلف

Table 2: Distribution of settlements in different climatic classes

\begin{tabular}{|c|c|c|}
\hline $\begin{array}{l}\text { درصد } \\
\text { Percent }\end{array}$ & $\begin{array}{l}\text { تعداد استقرارها } \\
\text { Number of } \\
\text { settlements }\end{array}$ & $\begin{array}{c}\text { طبقات اقليمى } \\
\text { Climate classes }\end{array}$ \\
\hline 50 & 7 & $\begin{array}{c}\text { كرم و خشك } \\
\text { Warm and dry }\end{array}$ \\
\hline 29 & 4 & $\begin{array}{l}\text { معتدل و مرطوب } \\
\text { mild and humid }\end{array}$ \\
\hline 21 & 3 & $\begin{array}{c}\text { سرد و كوهستانىى } \\
\text { Cold and mountainous }\end{array}$ \\
\hline
\end{tabular}

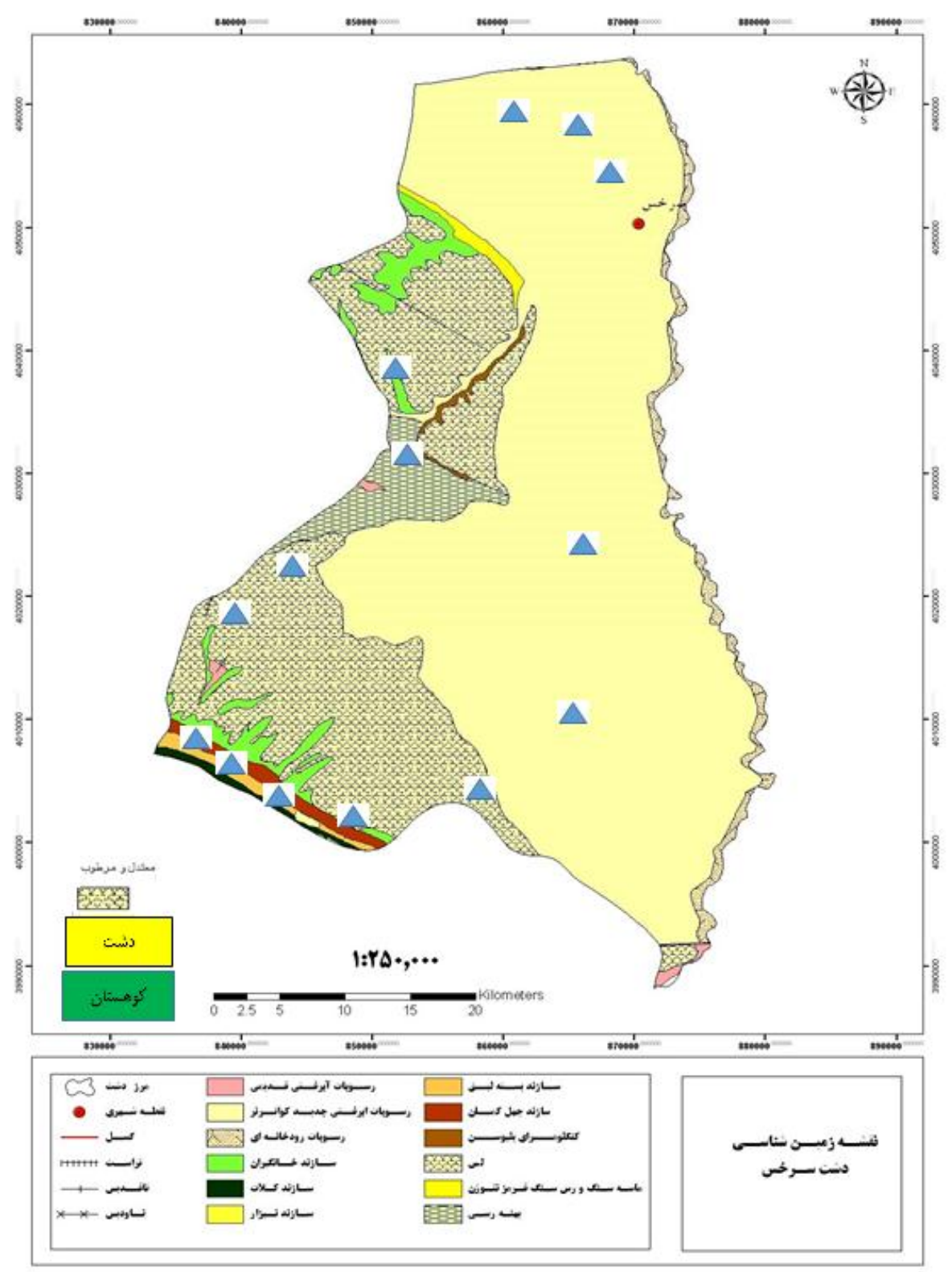

شكل \: موقعيت استقرارها در طبقات اقليمى [14]

Fig. 7: Location of settlements in climatic classes [14] 
محدودة موردمطالعـه، الخَــىى قراركيـــى ايـن اسـتقر ارها

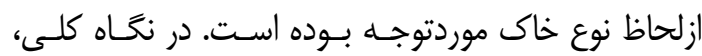
خاكهاى دشت سرخس به دو گَروه تقسيه مىشـوند كـهـ عبارت هستند از: إ- خاكهاى اغلب رسوبى كه بلهوسـيلة رودخانهها، سيلابها و يا آبيارى بر جاى كذاشته شدهانـد.

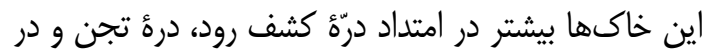

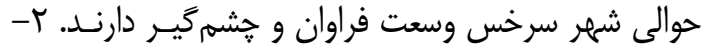

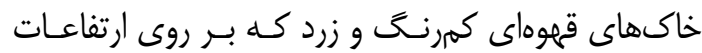

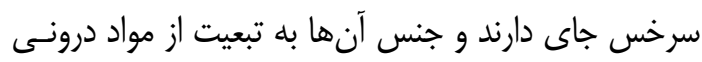

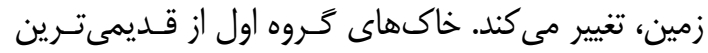

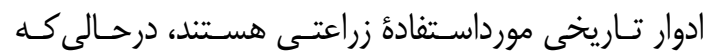

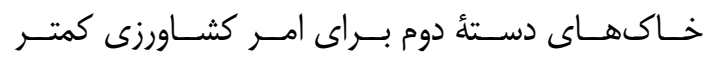

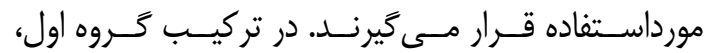
خاكهاى رسى، ليمونى و شنى، با عمق و شورى مختلـف

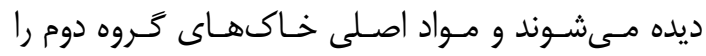

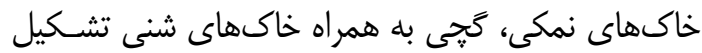

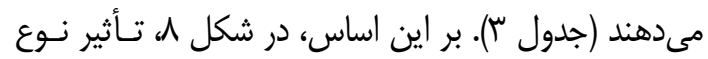

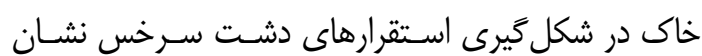

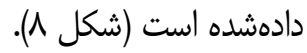

كاربرى زمين: از ديخر مؤلفههاى مؤثر در شكل گئرى و و يراكندگى محوطههاى باستانى، نوع كاربرى زمين ها است.

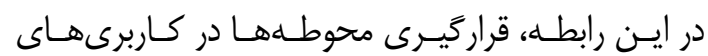

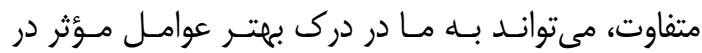

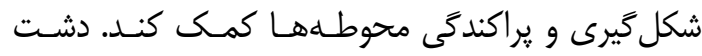

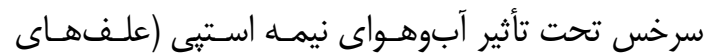

درجئ حرارت در منطقة مزبور، از آمار ايستخاههاى موجـود

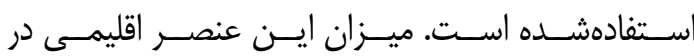

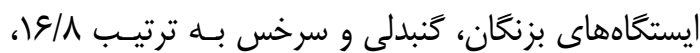
آرا و ها ها درجئ سليسيوس محاسبه شده است. بر اساس

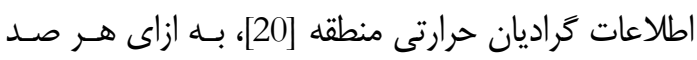

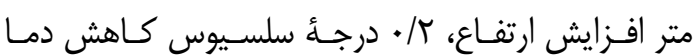

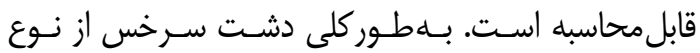
آبوهواى گرم و خشك در دشت، معتدل و كوهستانى در

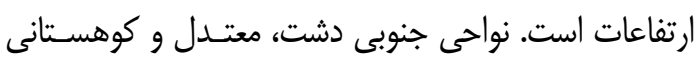
است و زمستان سرد و يربرف، ولى تابستـان هـاى معتــل

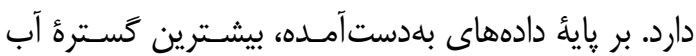

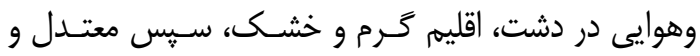

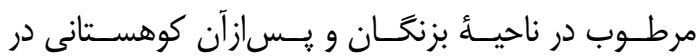

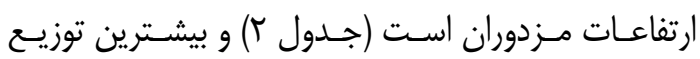
سكونتخاههاى مسكونى نيـز در دشـت و ســــ دو اقلـيم

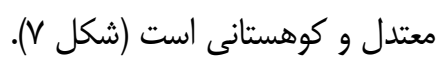

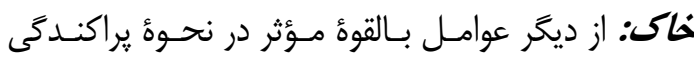

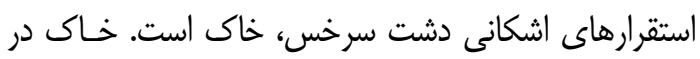

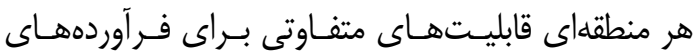

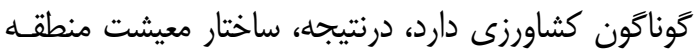

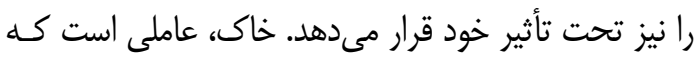

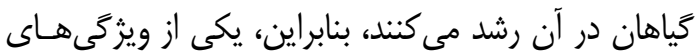
مهرم و اساسى خاك، عمق آن است. در توزيع استقرارهاى

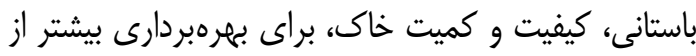

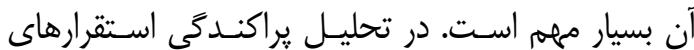

جدول سا: توزيع استقرارها بر بايئ نوع خاى

\begin{tabular}{|c|c|c|}
\hline $\begin{array}{c}\text { Pرصد } \\
\text { Percent }\end{array}$ & $\begin{array}{l}\text { تعداد استقر ارها } \\
\text { Number of } \\
\text { deployments }\end{array}$ & $\begin{array}{l}\text { نوع خاى } \\
\text { Soil type }\end{array}$ \\
\hline 29 & 4 & $\begin{array}{l}\text { خاكهاى رسوبى شور } \\
\text { Saline sedimentary soils }\end{array}$ \\
\hline 7 & 1 & $\begin{array}{c}\text { خاكهاى شور قليايى } \\
\text { Alkaline saline soils }\end{array}$ \\
\hline 14 & 2 & 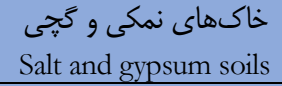 \\
\hline 36 & 5 & خاكىهاى سيرزم \\
\hline 14 & 2 & $\begin{array}{c}\text { خاكهاى برون } \\
\text { Outer soils }\end{array}$ \\
\hline
\end{tabular}

Table 3: Distribution of settlements by soil type

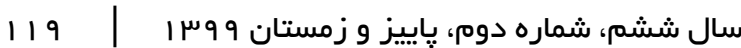




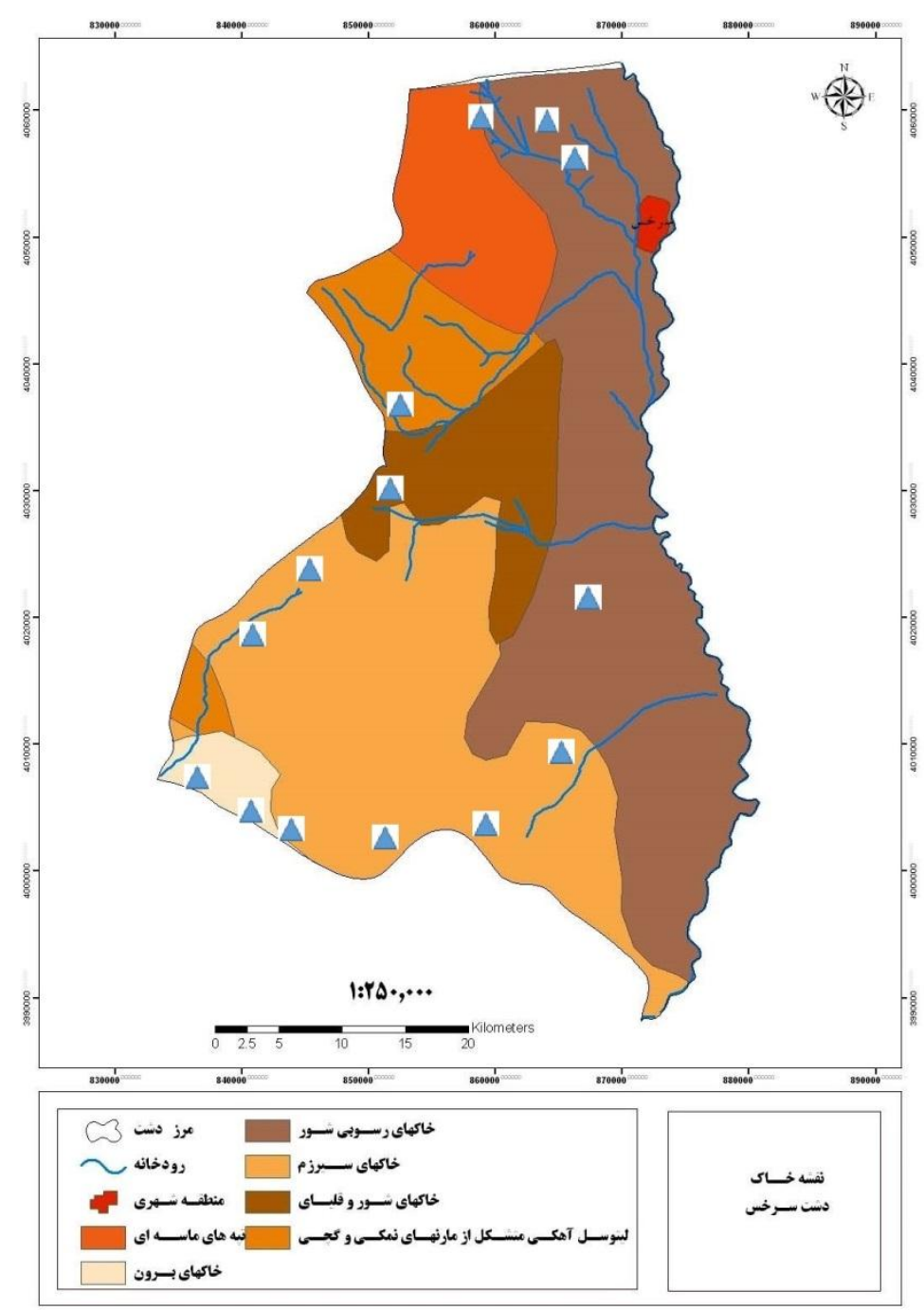

شكل ᄉ: موقعيت استقرارها نسبت به طبقات نوع خاى [21]

Fig. 8: Position of settlements in relation to soil type classes [21]

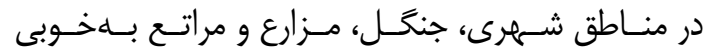

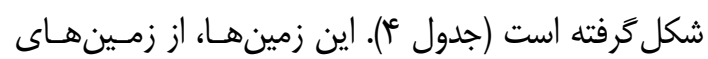

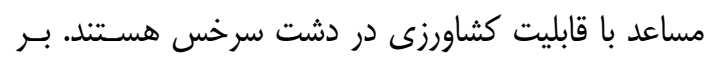

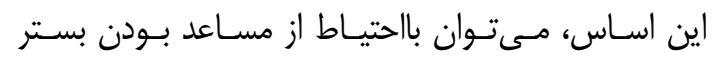

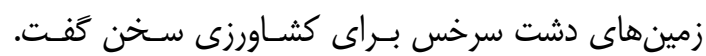

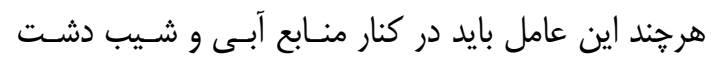

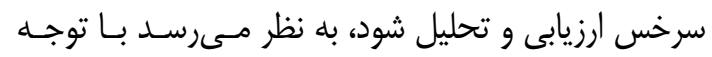

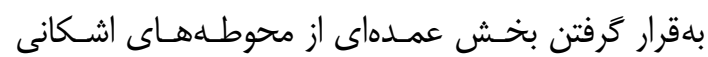

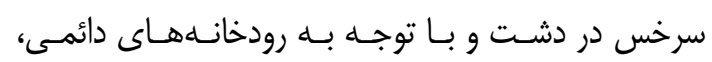

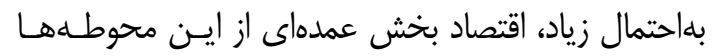

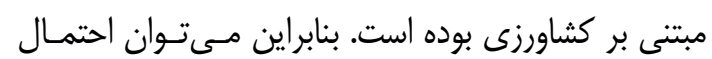

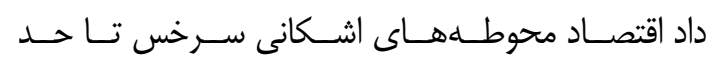

كوتاه)، جنس خاك، بِستىوبلنـدى داراى يوشـش گيـاهى

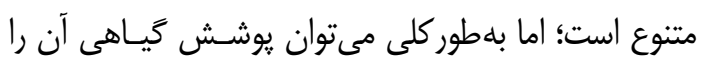

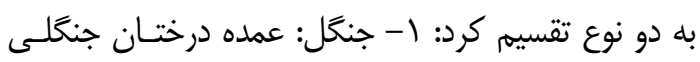

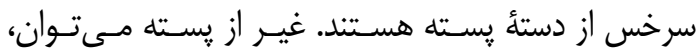

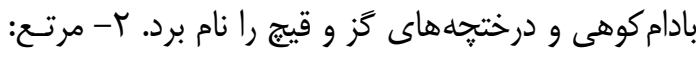

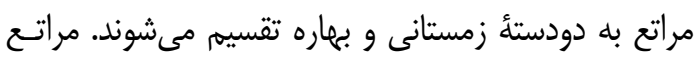

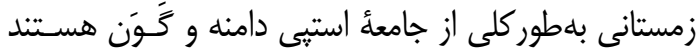

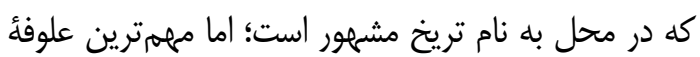
بهارى سرخس، نبات جهل روززه (نوعى خوراك دام) اسـت.

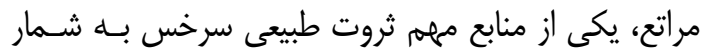

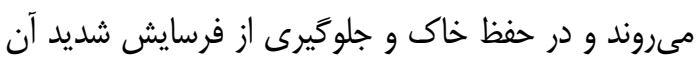

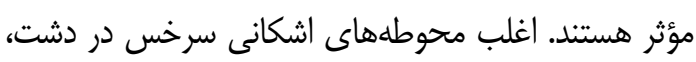

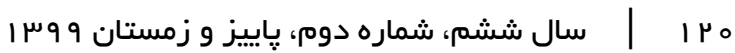


جدول عا: توزيع استقرارها بر קايئ زمين و يوشش كياهى

Table 4: Distribution of settlements based on land and vegetation

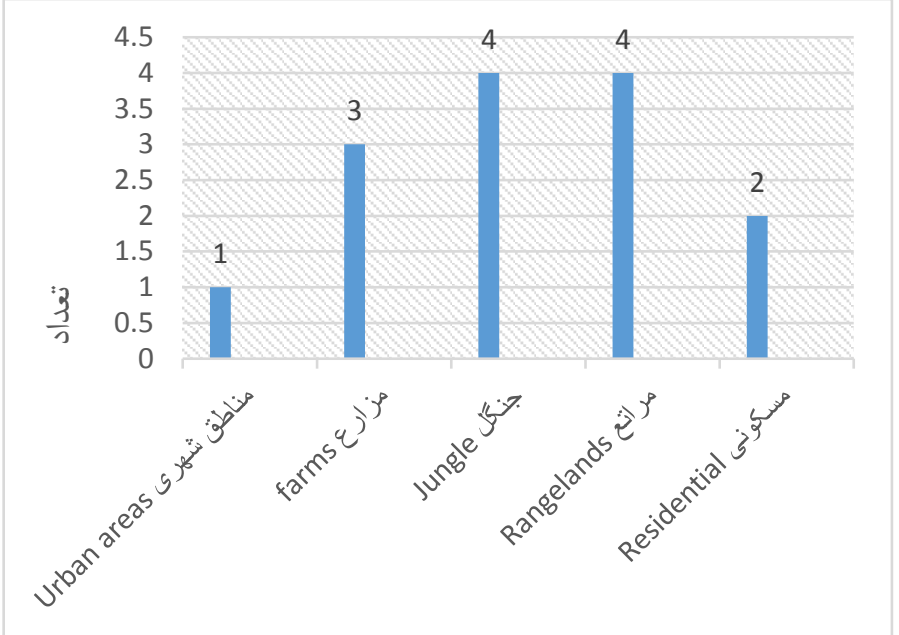

\begin{tabular}{|c|c|c|}
\hline $\begin{array}{c}\text { درصد } \\
\text { Percent }\end{array}$ & $\begin{array}{c}\text { تعداد استقرارها } \\
\text { Number of deployments }\end{array}$ & $\begin{array}{c}\text { كاربرى اراضى } \\
\text { Land use }\end{array}$ \\
\hline 7 & 1 & $\begin{array}{l}\text { مناطق شهرى } \\
\text { Urban areas }\end{array}$ \\
\hline 21 & 3 & $\begin{array}{l}\text { مزاع } \\
\text { farms }\end{array}$ \\
\hline 29 & 4 & $\begin{array}{l}\text { جنگً } \\
\text { Jungle }\end{array}$ \\
\hline 29 & 4 & $\begin{array}{c}\text { مراتع } \\
\text { Rangelands }\end{array}$ \\
\hline 14 & 2 & $\begin{array}{c}\text { مسكونى } \\
\text { Residential } \\
\end{array}$ \\
\hline
\end{tabular}

شكل 9: تعداد استقر ارها نسبت به نوع اراضى

Fig. 9: Number of settlements by land type

\section{0. رتبلبندى عوامل محيطى مؤثر در شكلَّيرى

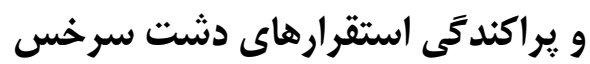

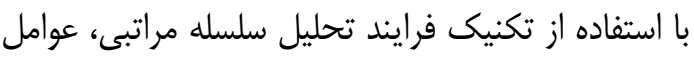

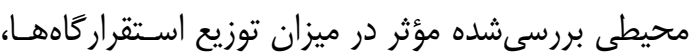

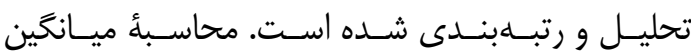

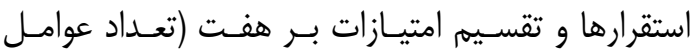

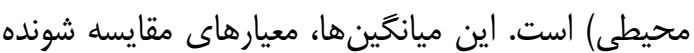

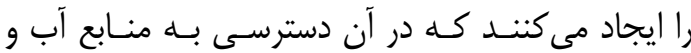

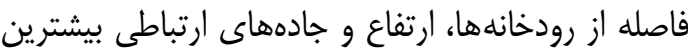

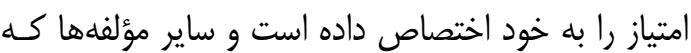

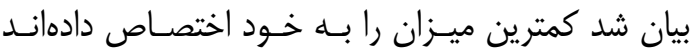

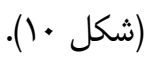

قابلتوجهى مبتنى بر كشاوزى بوده است. مسـاعد بـودن

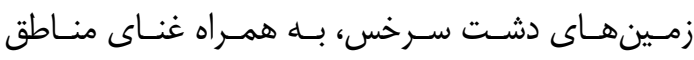

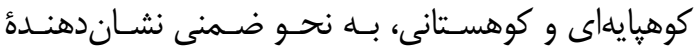

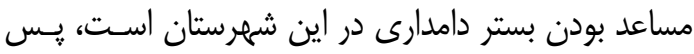

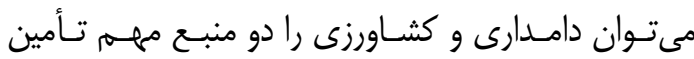

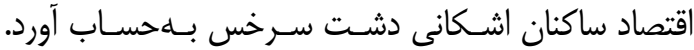

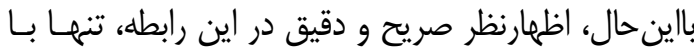
كاوشهاى كسترده در محوطههاى اشكانى اين شهرستان

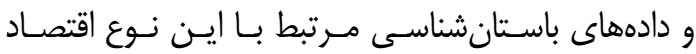

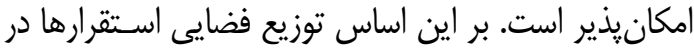

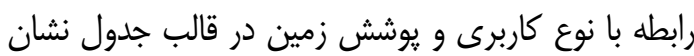

دادمشده است (شكل 9 9) 


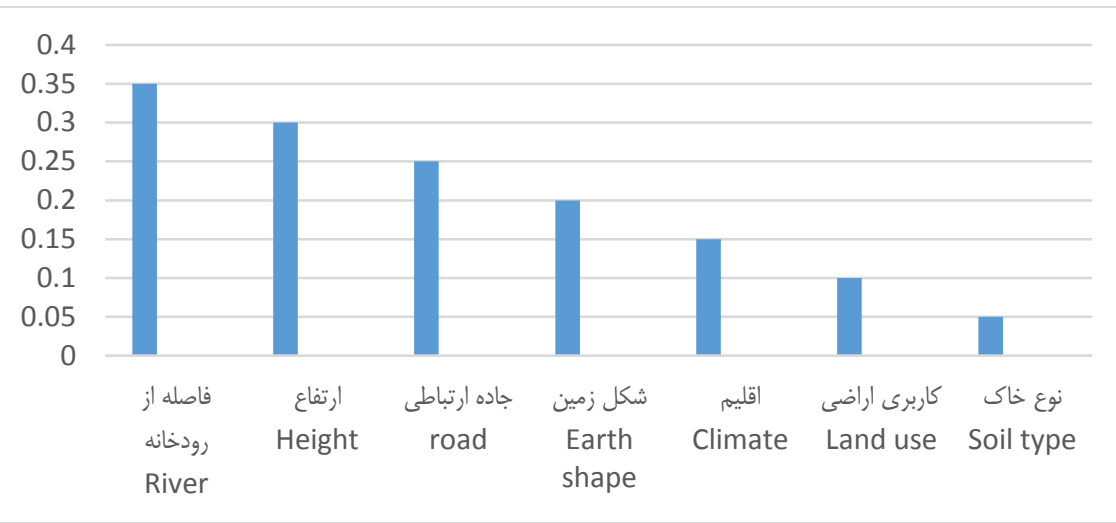

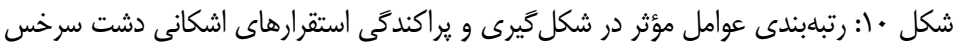

Fig. 10: Ranking of effective factors in the formation and dispersal of Parthian settlements in Sarakhs plain

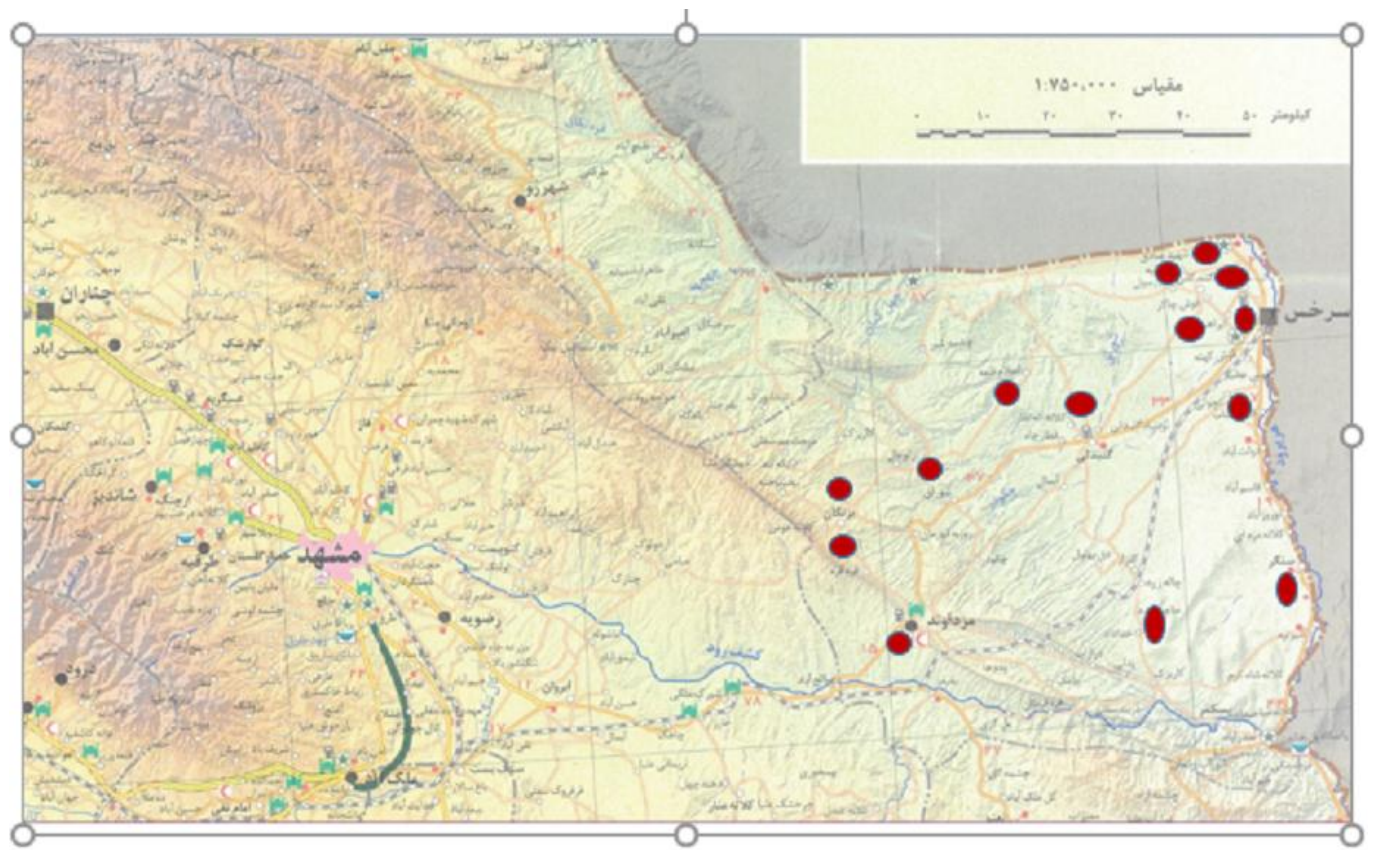

شكل [1: براكنش جغرافيايى استقرارهاى اشكانى دشت سرخس [14]

Fig. 11: Geographical distribution of Parthian settlements in Sarakhs plain [14]

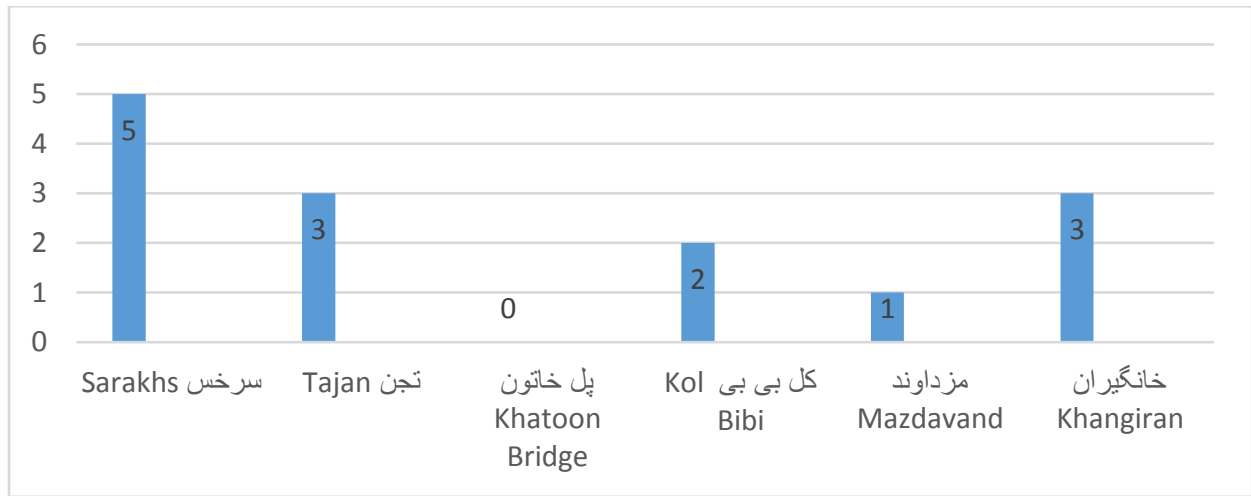

شكل r ا: فراوانى استقرارهاى اشكانى دشت سرخس

Fig. 12: Frequency of Parthian settlements in Sarakhs plain 


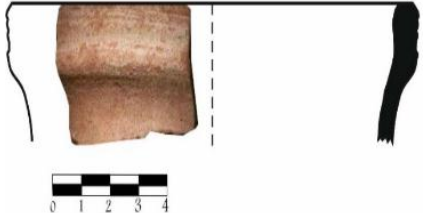

مادر بيگ Beyg Mother
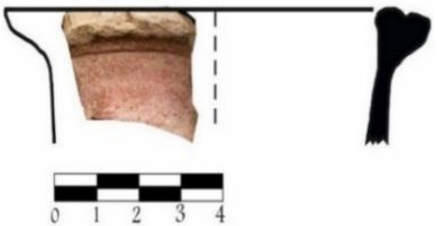

Chel

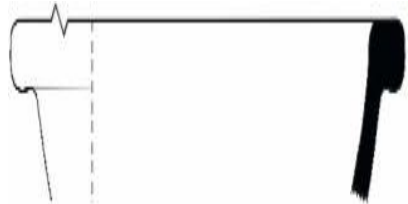

푸무

كجولى Kachooli

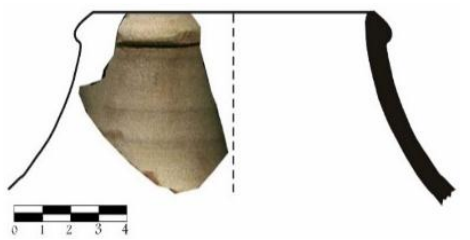

White سفيد

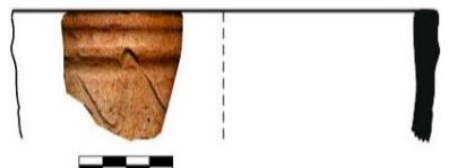

Yaz
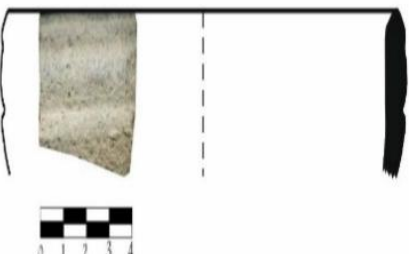

جل كمان Chel Kaman

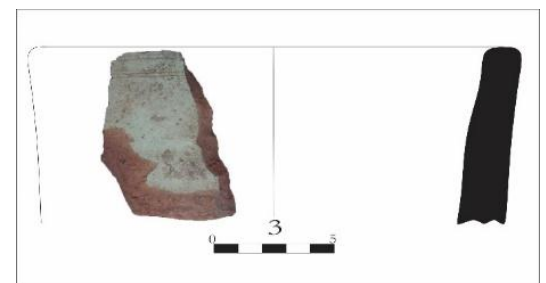

Esmaeel Abad اسماعيل آباد

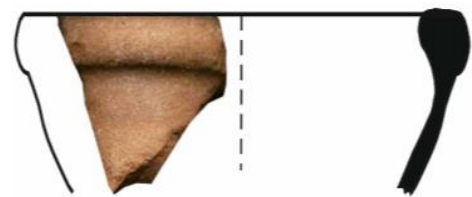

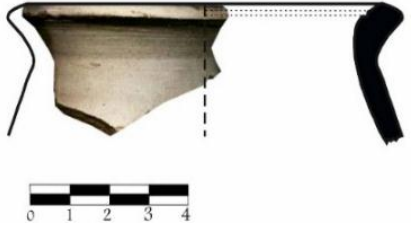

خونى Khooni

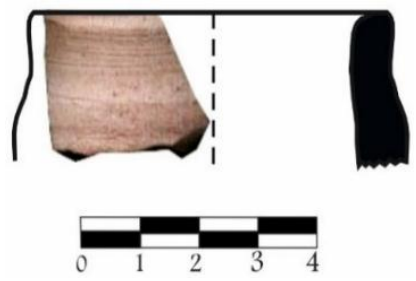

Allah Madad الله مدد

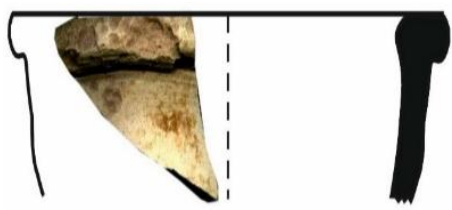

MIR Ahmad مير احمد
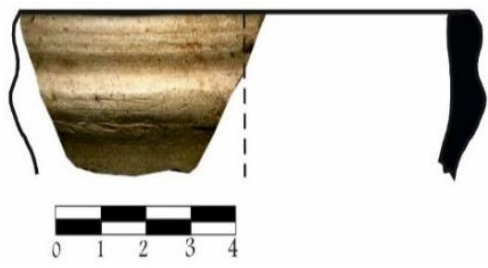

Abbas Abad عباس آباد
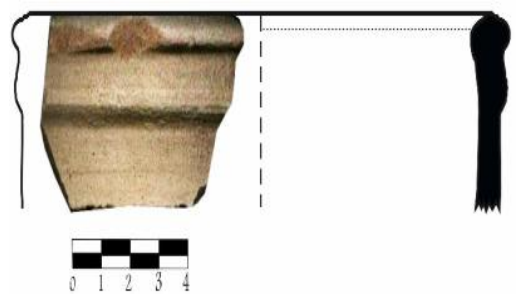

غرغره Ghor Ghoreh

Bazangan بزنغان

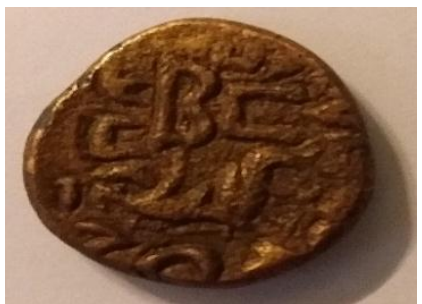

آب دراز Ab Deraz شكل سا: تصوير برخى قطعات سفال و سكه استقرارهاى اشكانى دشت سرخس

Fig. 13: Picture of some pottery and coins of Parthian settlements in Sarakhs plain

مىتــوان هنـر و مؤلفـهـهـاى فرهنحَى دورة اشـكانيان،

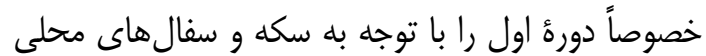

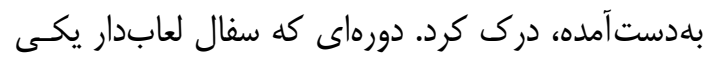

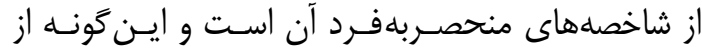

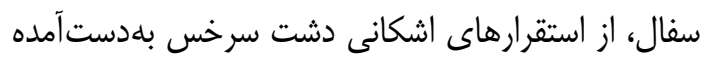

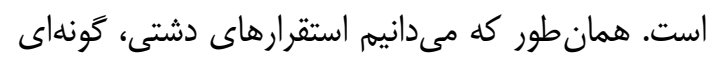

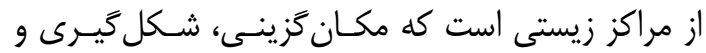

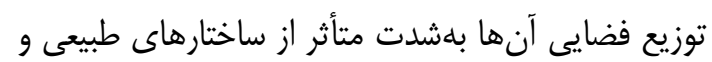

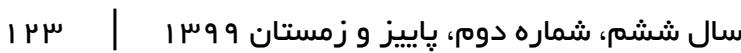

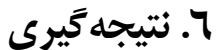

با توجه به خاستخاه اشكانيان در شمال شرق ايران دشت سرخس هدف يك بررسى روشمند ميدانى قرار كرفت تأن

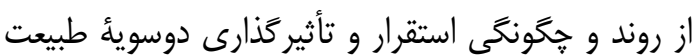
و انسان در منطقه، درك درستى حاصل شود. نتيجأ اين بررسى، شناسايى جهارده محوطه استقرارى از ايـن دوره

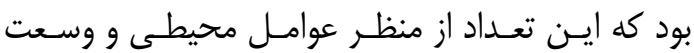

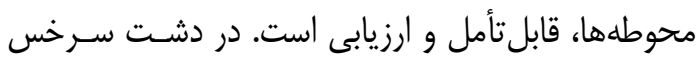


بزرگتر است. وجود رودخانههايى خون كشفرود، تجن،

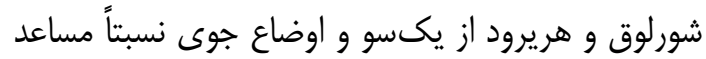
دارت از سوى ديخر، نشان از استقرارهاى دورئ واء اشكانيان

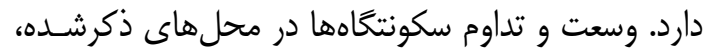

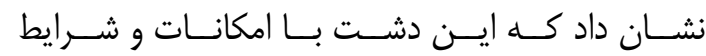

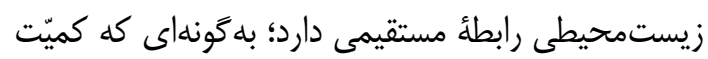

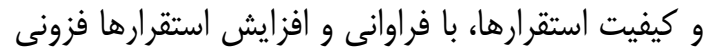

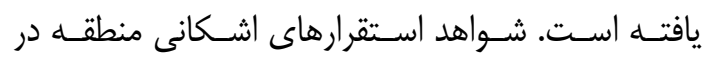

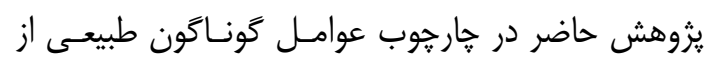

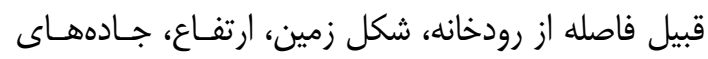

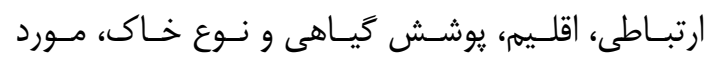

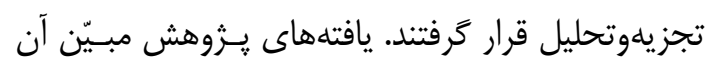

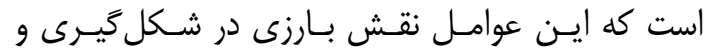

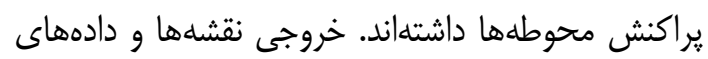
استقرارهاى اشكانى منطقه، نشان داد كه از ميان عوامل

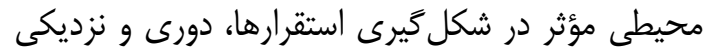

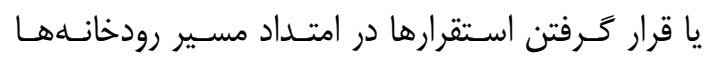

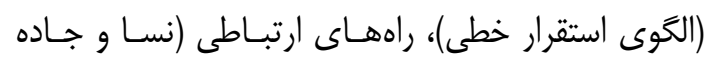

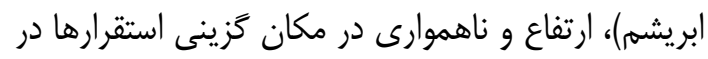

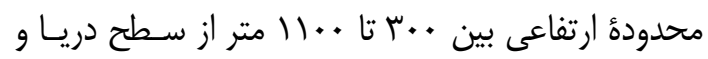

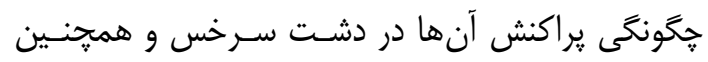
ارتفاعات در شكل خيرى استقرارها، بيشتر از ساير عوامل

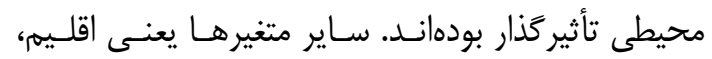

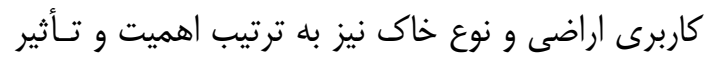

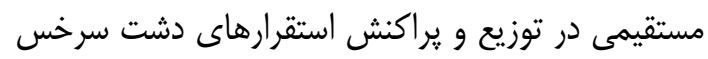

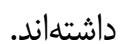

\section{References}

[1] Herring Ernie. Hamideh Chubak. Iranian pottery in the Parthian period. Tehran: Cultural Heritage Organization; 1391; p.26. [in Persian].

] هرينگ ارنى. حميــه خوبـــ سـفال ايـران در دوران

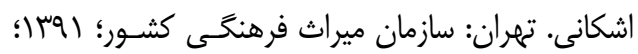

ص ص פ.

[2] Fray Richard. Zahra Basti. History of Iran during the Parthian and Sassanid eras in Mesopotamia. Tehran: Organization for the Study and Compilation of University Humanities Books (Samt); 1389; p.22. [in
عوامل محيطى است. بالينوجـود، در ايـن نـواحى، بـين

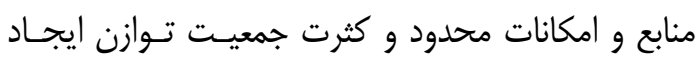

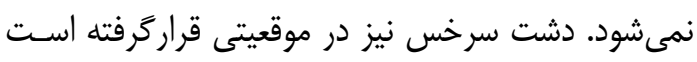

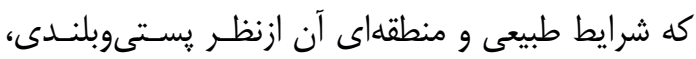

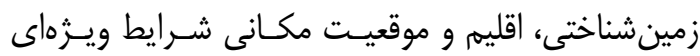

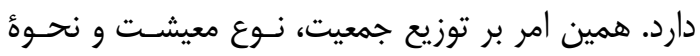

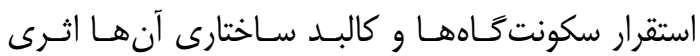

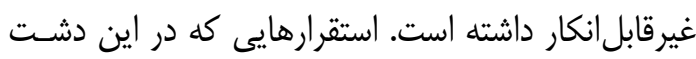

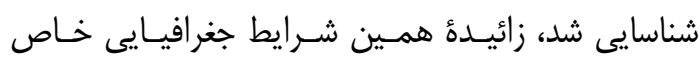

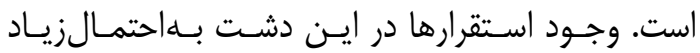

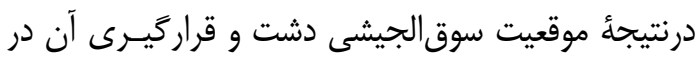

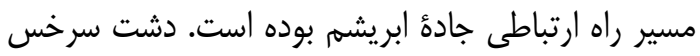
بهواسطة نزديكى به جنوب تر كمنستان و شهر نسا، يكى إنى

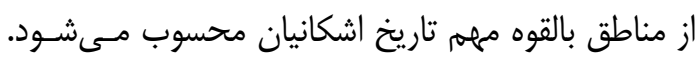

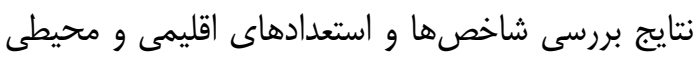
اين دشت نشان از تفاوتهاى معنادارى بين قسمتهاي كوناگون دشت دارد. جنان كه بسيارى از استقرارها سابقه

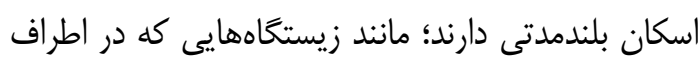

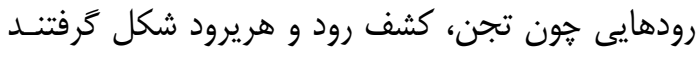

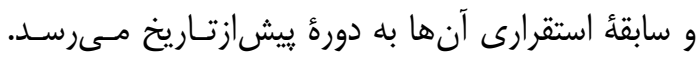
جمعيتيذيرى غرب سرخس و حوالى بزنخـان، بـرخلاف

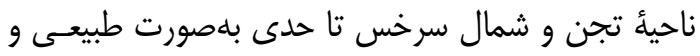

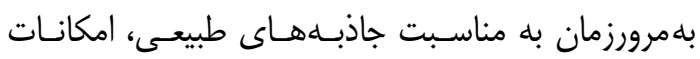
كشاورزى و دامدارى صورت يذيرفته است. اسـتقرارهاى مركزى دشت سرخس نمايانكر توسعة جمعيـت، اقتصـاد

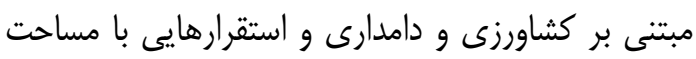

Persian].

] فــراى ريجـارد. زهـــا باسـتى. تـاريخ ايـران در دوران اشكانى و ساسانى در بين النهرين. تهران: سازمان إنـان مطالعه

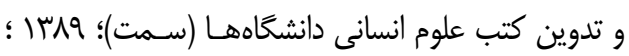

ص صזr]

[3] Ebrahimi Zanganeh. Discovery record report. Tehran: Cultural Heritage Organization; 1384; p.8 [in Persian].

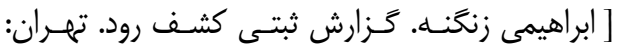

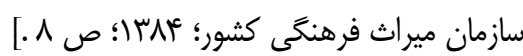

[4] Nami Hassan. Proposed analysis and

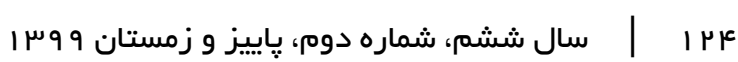


chronology of Chapashloo hill town in Dargaz city; Northeast of Iran, Archaeological Research of Iran: February 2017; pp. 124-126. [in Persian].

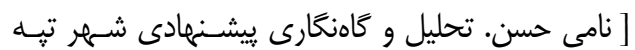

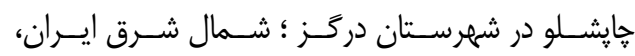

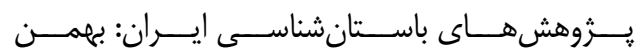

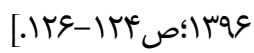

[5] Basafa Hasan. Explain the pottery characteristics of the early Parthian period in the Kashfarud basin; Based on the typology of Ismail Abad hill pottery in Mashhad, Archaeological studies: 1397; Volume 10; Number; p 27. [in Persian].

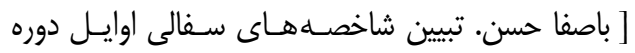

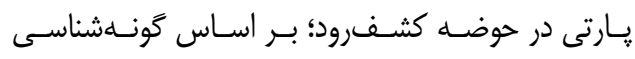

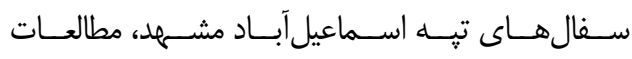

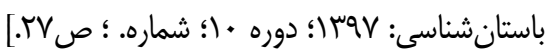

[6] Maab Consultants. Strategic and operational structure of tourism in Khorasan Razavi province: basic environmental studies; Cultural Heritage Organization of the country; 1389; p.1. [in Persian].

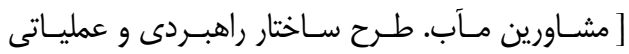

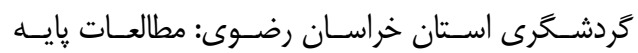

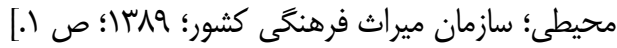

[7] Yousefian Morteza. Investigation of geomorphology units and its relationship with groundwater resources in Sarakhs plain: Master's thesis, Sabzevar Teacher Training University: Faculty of Geography; 1390; p. 3. [in Persian].

] يوسفيان مرتضى. بررسـى واحـدهاى زئومورفولـوزى و .

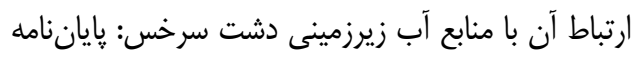

دوره كارشناسـى ارشــ، دانشــاه تربيـتمعلـم ســبزوار:

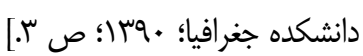

[8] Nami Hassan. Archaeological study of Parthian sites in Dargaz city; Northeast of Iran, Archaeological Studies: February 2017; p. 17. [in Persian].

$$
\begin{aligned}
& \text { ] نامى حسن. بررسى باستانشناسى محوطههاى اشكانى }
\end{aligned}
$$

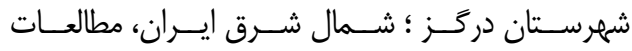

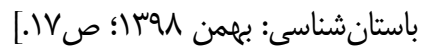

[9] Rahbar Mahdi. Archaeological excavations of Dargaz Bandian; Archaeological reports; 1376; p.17. [in Persian].

] رهبر مهدى. كاوشهاى باستان شناختى بنـديان درگَز؛؛

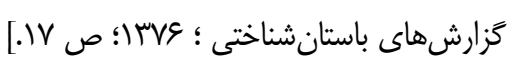

[10] Cellerino, A. $r \cdots \wedge$ La ceramica. in: Invernizzi, A., Lippolis, C. (eds.), Nisa Partica. Ricerche nel compleso monumentale Arsacide. Monografie di Mesopotamia IX. Le Lettere, Firenze, pp. $r+9-19 v$.

[11] Usmanova, ZI,1963. Erk-Kala (based on the materials of STACE 1955-1959) TUTAKE (TЮТАКЭ) XI:20-94.

[12] Binford, L. R. 1982 "The Archaeology of Place", Journal of Anthropological Archaeology, Vol. 1, PP. 5-31.

[13] Ashmore. W, 1999, Archaeologies of Landscape: Contemporary Perspectives, Oxford: Blackwell.

[14] Geological Survey of Iran. Geological map of settlers and mercenaries; 1383. [in Persian].

$$
\begin{aligned}
& \text { ] سـازمان زمـينشناسـى كشـور. نقشــــ زمـينشناسـى } \\
& \text { خان گيران و مزدوران؛ سمبسا. }
\end{aligned}
$$

[15] Ministry of Energy. Sarakhs Groundwater Report; 1383; p.34. [in Persian].

[ وزارت نيرو. گزارش آبهاى زيرزمينى سرخس؛ سئا؛

ص

[16] Mousavi Nia Seyed Mehdi. Khomein city
in Parthian and Sassanid eras based on archaeological studies; Central research culture; 1393; Year 1 (2) p 28. [in Persian].

[ موسوىنيـا سـيد مهـــى شهرسـتان خمـين در دوران

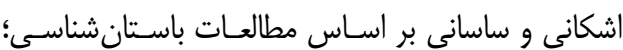

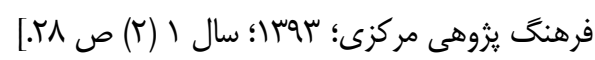

[17] Altheim Frants. Houshang Sadeghi. Writings on Parthian history and culture. Tehran: Elam; 1389; p.20. [in Persian].

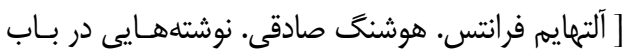

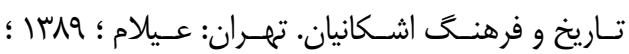

$[. r \cdot 0$

[18] Saeedi Abbas.Sarakhs yesterday and today. Toos: University of Tehran; 1354; p.4. [in Persian].

$$
\begin{aligned}
& \text { [ سعيدى عباس. سرخس ديروز و امروز. توس: دانشـعاه }
\end{aligned}
$$

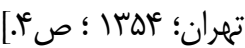

[19] Ahmadi, Mohammad Sarakhs Naseri. Mashhad: Astan Quds Razavi; 1391; p. 43. [in Persian].

$$
\text { ] احمدى، محمد. سرخس ناصرى. مشهلد: آستان قـدس }
$$




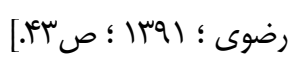

[20] Reports of the Meteorological Organization of the country. Razavi Khorasan: Sarakhs city; 1382; p.64. [in Persian].

$$
\text { [ گزارشات سازمان هواشناسى كشور. خراسـان رضـوى: }
$$

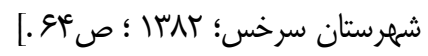

[21] Organization of Forests and Rangelands of the country. Detailed-executive studies; 1381; pp.100-112. [in Persian].

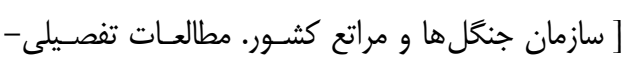

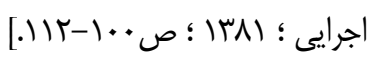

